\title{
Specialization in food production affects global food security and food systems sustainability
}

\author{
Mercedes Campi ${ }^{\mathrm{a}, *}$, Marco Dueñas $^{\mathrm{b}}$, Giorgio Fagiolo ${ }^{\mathrm{c}}$ \\ ${ }^{a}$ CONICET - University of Buenos Aires, Faculty of Economics, IIEP, Argentina \\ ${ }^{\mathrm{b}}$ Department of Economics, International Trade and Social Policy, Universidad de Bogotá Jorge Tadeo Lozano, Colombia

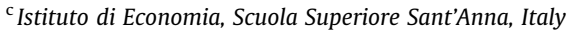

\section{A R T I C L E I N F O}

\section{Article history:}

Accepted 14 January 2021

\section{Jel:}

Q01

Q18

F63

\section{Keywords:}

Specialization

Diversification

Food supply

Food security

Sustainability

Complex networks

Bipartite networks

\begin{abstract}
A B S T R A C T
Understanding specialization patterns of countries in food production can provide relevant insights for the evaluation and design of policies seeking to achieve food security and sustainability, which are key to reach several Sustainable Development Goals (SDGs). This paper builds bipartite networks of food products and food-producing countries, using FAO data from 1993 to 2013, to characterize the global food production system. We use methods from complex systems analysis to rank products according to their need for capabilities and countries according to their competitiveness, which derives from the quality and diversification of their food production baskets. We observe two well-defined communities of food-producing countries, one that groups countries with relatively developed agricultural systems, and the other grouping countries with less developed production systems. The stability of these two communities reveals persistent differences between countries specialization patterns. We econometrically analyze whether and how specialization patterns affect food supply, food security (SDGs: Targets 2.1 and 2.2), and sustainability of food systems (SDGs: Target 2.4). We show that concentrating agricultural production negatively impacts food supply, food security, and food systems sustainability. The competitiveness of countries and the coherence of their diversification patterns increase per capita food supply and food security but might harm sustainability. This evidence reflects the trade-off between achieving food security while simultaneously improving sustainability, which needs to be considered when developing or implementing policies seeking to reach SDGs.
\end{abstract}

(C) 2021 Elsevier Ltd. All rights reserved.

\section{Introduction}

Achieving global food security and sustainable food systems has become a growing challenge at the international policy level. Given its relevance, the global food system appears as a key element in several Sustainable Development Goals (SDGs) (United Nations, 2015). In particular, the second SDG (zero hunger) seeks to simultaneously address global environmental sustainability and food security challenges, including improved nutrition leading to a healthy life. Thus, the broad scope of the SDGs requires holistic approaches, integrating food sustainability assessments (Chaudary et al., 2018; Blesh et al., 2019).

Our understanding of the global food system is still in a development stage (Puma, 2019). Although there is an increasing agree-

\footnotetext{
* Corresponding author.

E-mail address: mercedes.campi@fce.uba.ar (M. Campi).
}

ment in the need for a comprehensive and holistic perspective for studying how food systems contribute to achieving food security and sustainability, the related studies tend to be framed within distinctive disciplinary narratives (Béné et al., 2019a; Liu et al., 2015). Partly because of their complexity, food systems and sustainability concepts remain poorly defined and applied in different ways, although more holistic concepts have gathered strength recently (Béné et al., 2019c).

Multiple factors have been placing unprecedented pressure on food systems: population growth (Godfray et al., 2010), dietary changes (Barabási et al., 2020), overexploitation of natural resources (Hazell \& Wood, 2007; Cassidy et al., 2013), increasing biofuels and biomass use (Woods et al., 2010; Nonhebel \& Kastner, 2011), and climate change (Battisti \& Naylor, 2009; Gornall et al., 2010). Similarly, food security and sustainability are affected by economic, social, and environmental drivers. 
Understanding these changes, their implications, and the interactions among these drivers is complex but critical when addressing the challenge of meeting a more sophisticated demand for nutritious food for a growing world population under climatic pressures while moving towards more sustainable food systems and mitigating associated environmental damage (Ericksen, 2008; Béné et al., 2019b).

Historically, along with technological progress to increase yields, the food needs for growing populations were met by expanding the cultivated area. By the twentieth century, public investments in modern scientific research for agriculture led to dramatic yield breakthroughs (Evans, 1998). As a consequence, most high-income countries achieved sustained food surpluses in the mid-twentieth century. Many developing countries did the same in recent decades, except for Africa, which has not yet achieved food surpluses (Hazell \& Wood, 2007). Today, more food is produced than is needed to feed the entire world population. Thus, the current fundamental problem of hunger is one of income distribution rather than food shortages. Despite technological progress, differences in production trajectories of countries have been persistent. Moreover, technological gaps are widening due to differences in research and development spending (Pardey et al., 2016).

The production gap is partly associated with differences in countries capabilities to produce food, including environmental conditions, technology, capital, institutions, and skills. These capabilities are related to differences in farming systems and productive capacity, population densities, growth, evolving food demands, infrastructure, market access, and countries capacity to import food and invest in agriculture and environmental improvement (Hazell \& Wood, 2007). The current gaps in food production and food access seem to be greatly defined by differences in per capita incomes, which proxy their development levels. Therefore, capabilities for food production, which are unevenly distributed within and between countries, define countries food production baskets.

In turn, the composition of production baskets, including the variety of products that countries choose or are able to produce and consume, can affect their food security and the sustainability of their food systems. Food demand influences agricultural production, and agricultural practices can result in pollution and biodiversity loss (Marlow et al., 2009). Dietary choices link environmental sustainability and human health, with alternative options of sustainable diets that can improve them (Tilman \& Clark, 2014; Johnston et al., 2014). Besides, food systems contribute to and are impacted by climate change. Therefore, production, diets, health, and the environment are linked through embedded connections, some of which have developed relatively quickly and are rapidly evolving. Thus, there is a need for better characterization and understanding of the complexity of food production and specialization patterns.

In this paper, we consider the global food system as an evolving, complex, dynamic, and highly interconnected network of activities, which involve a high number of heterogeneous stakeholders (Lowder, Skoet, \& Raney, 2016; Puma, 2019). We characterize food systems and capabilities for food production using a data-driven approach to measure emergent features of agricultural specialization patterns of countries and their competitiveness. Then, we provide evidence on how specialization in food production affect food supply, multidimensional aspects of food security (SDGs: Targets 2.1 and 2.2), and sustainability of food systems (SDGs: Target 2.4).

Our analysis focuses on food production, and it is based on a broad theoretical background that analyzes how countries specialize in the production of different products. Building on the evidence presented in (Campi et al., 2020), we use bipartite network analysis to study the agricultural production space. Then, we clas- sify countries by their competitiveness, considering the quality and diversity of their food production baskets. Finally, we perform an econometric analysis to evaluate how countries competitiveness, the coherence of diversification patterns, and production concentration affect per capita food supply, food security, and the sustainability of food systems.

We address the following questions: (1) How are countries classified according to their capabilities and their food production patterns? (2) How do different production baskets affect food supply, food security, and food systems sustainability? In particular: (a) What is the effect of concentrating production? (b) What is the impact of a coherent diversification of food production? and (c) What is the effect of the countries competitiveness, considering the diversity and quality of their food production baskets?

This paper has two main contributions. First, it shows that foodproducing countries are empirically and consistently classified into two groups defined by their revealed capabilities with different features and performance, reflecting a persistent gap in their production capabilities. Second, it shows that food specialization patterns affect countries food supply, food security, and the sustainability of food systems. The analysis of agricultural specialization patterns provides relevant insights for developing policies seeking to reach the SDGs and achieve sustainability in food security and food systems.

The remaining of the paper is organized as follows. Section 2 presents the theoretical background and a brief literature review. Section 3 describes the data. Section 4 explains the methodology. Section 5 presents the main results. Section 6 discusses the results. Finally, Section 7 concludes.

\section{Theoretical background and literature review}

How and what countries produce has been a fundamental concern in economics because it has been linked to economic development. According to Ricardo (1817), production factors specialize in different economic activities based on their relative productivity differences. Thus, countries' endowments determine their specialization patterns, and revealed comparative advantages are generally used to measure a country relative advantage in producing a particular good. These ideas have derived in other well-diffused approaches such as that of Heckscher \& Ohlin (1991). Other perspectives consider that not only endowments, such as land, labor, and capital, determine specialization and comparative advantages, but also capabilities, which are defined in a broad sense, including technology, capital, institutions, infrastructure, skills, and tacit knowledge (Lall, 2000).

A recent stream of literature has applied methods from complex networks to study how capabilities shape the production of different types of products and how this helps economic development (Hidalgo \& Hausmann, 2009; Caldarelli et al., 2012; Tacchella et al., 2012; Cristelli et al., 2013; Hausmann et al., 2014; Zaccaria et al., 2014; Balland \& Rigby, 2017). These studies assume that different products are jointly produced because they require similar capabilities (Teece et al., 1994). Thus, although we cannot directly observe the set of capabilities necessary for production, the fact that different countries produce identical products may indicate that these countries share capabilities that are needed to produce these products. Based on these ideas, these studies build the world product space network, where more sophisticated products are located in a densely connected core, and less sophisticated products occupy a less connected periphery. The possibilities of diversification into new products are strongly determined by the capabilities revealed in the products currently produced. 
This type of analysis can also be applied to agricultural and food production (see, Campi et al., 2020) to study production patterns and characteristics, such as diversification, concentration, and competitiveness. We argue that this analysis can provide relevant insights for understanding the effect of production patterns on food supply, food security, and food systems sustainability.

With food systems undergoing relevant changes, countries have been facing significant challenges in producing more food for an increasing population and diversifying production in response to changes in diets while addressing environmental problems. Although the food system is currently able to produce more food than needed for the world population, there are persistent differences in production patterns and food distribution. The need to end hunger in some regions and move towards healthier diets in others while addressing environmental problems is at the core of the SDGs, placing food systems as key elements. Sustainable diets can advance commitments to sustainable development and the elimination of poverty, food and nutrition insecurity, and poor health outcomes (Johnston et al., 2014).

The analysis of food production patterns can help policies seeking to provide a nutritious diet made up of diverse foods without harming the environment, which is a complex challenge for countries.

\subsection{Changes in diets, food production, and diversification}

During the past years, countries have been going through dietary changes towards more diverse foods, different nutrient composition, sustainability, and a variety of credence attributes (Finaret \& Masters, 2019; Barabási et al., 2020). Accordingly, agricultural production has diversified but has also become more similar in composition.

Different studies have shown an overall increase of the diversity of national food supplies, together with a homogenization across countries, during the last 50 years (Nelson et al., 2016; Aizen et al., 2019; Martin et al., 2019; Aguiar et al., 2020). Khoury et al. (2014) show that national food supplies have diversified, within a global trend of increased overall quantities of food calories, protein, fat, and weight. Simultaneously, food supplies have become increasingly similar in composition, based upon a suite of truly global crop plants. Similarly, Bentham et al. (2020) show that four predominant food-group combinations explain almost $90 \%$ of the cross-country variance in food supply. The growth in reliance worldwide on these crops or food groups heightens interdependence among countries regarding availability and access to food sources and plant genetic resources.

The changes in the composition of diets have been sensible to income. In recent years, some Asian countries, such as South Korea, China, and Taiwan, experienced the most extensive changes, with animal source foods and sugar, vegetables and seafood, and oilcrops, all becoming a more abundant component of the food supply. Instead, less developed countries, as those in sub-Saharan Africa, have diversified much less their diets (Bentham et al., 2020).

However, not all countries change their diets in the same way as their income increases, since idiosyncratic factors, such as geography and culture, can largely determine the diversification paths. Campi et al. (2020) show that technological, economic, political, and institutional factors, are relevant determinants of the similarity of countries production baskets, in addition to geographical, climatic, and environmental conditions. Choudhury \& Headey (2017) show that economic growth, urbanization, and demographic change successfully explain the diversification of food supplies over time. They also point out that other geographic factors can explain the persistence of differences in the diversification of food supplies across countries at similar development levels.
Different social, cultural, and economic factors determine the total availability of calories and the variety of products included in diets. Demand for agricultural products guided by dietary changes is one of the primary determinants of the diversification of food supplies either in local production or imports. (Remans et al., 2014) study food supply diversity finding that diversification patterns strongly depend on the income level of countries. For low-income countries, food supply diversity is due mainly to local capabilities, while for middle- and highincome countries, it mostly depends on food imports. Therefore, international markets contribute to the diversity of the national food supply. Aguiar et al. (2020) show that, within countries, the diversity of crop supply increased at a faster rate than the diversity of production and that the diversification of trade surpassed both. Within countries, diversification of trade involved a much faster diversity growth of imports compared to exports. Across countries, crop production homogenized at slower rates than crop supply, indicating that crop trade was important for explaining this decoupling. Thus, food trade has also been increasing, shaping, and homogenizing the variety of food at the country level.

Although most countries now consume more homogeneous food, not all countries have the necessary environmental conditions or comparative advantages to produce these generic products. Yet, different studies document the spread of crops beyond their centers of origin. Khoury et al. (2016) show that countries are highly interconnected regarding primary regions of diversity of the crops they cultivate or consume. Foreign crop usage has increased significantly over the past 50 years, including in countries with high indigenous crop diversity. Similarly, Martin et al. (2019) show that species-level taxonomic diversity of crops being cultivated on large-scale agricultural lands has increased linearly over the past 50 years.

Thus, crops are becoming more geographically ubiquitous for all the food balance components, although there are important exceptions, such as oil palm, which has increased its production concentrating in a few specialized countries (Aguiar et al., 2020). In fact, different food products have faced different evolution. For example, (Muhammad et al., 2011) show that staple foods are less sensitive to changes in income compared to non-staple foods.

Considering changes in diets and the related changes in food production is important to address the following research questions. How concentration affects food supply and food security? Does diversification of food production have a positive effect on food supply and food security?

\subsection{Food production and food systems sustainability}

Agricultural production is one of the primary sources of food supply and a major driver of climate change, changes in land use, depletion of freshwater resources, and pollution of terrestrial and aquatic ecosystems (Steinfeld et al., 2006). Agriculture releases more than $25 \%$ of all greenhouse gases, pollutes fresh and marine waters with agrochemicals, and uses as cropland or pastureland about half of the ice-free land area of earth (Tilman \& Clark, 2014).

Similarly, diets can also affect food systems sustainability through different channels. For example, dietary composition strongly influences greenhouse gases emissions (Marlow et al., 2009; Springmann et al., 2018). In general, diets worldwide have become more diversified but also concentrated in a few main products that contain higher processed foods, refined sugars, refined fats, oils, and meats, which has caused important health problems, such as overweight or diabetes type II, and changes in biodiversity and the environment. Tilman \& Clark (2014) study how dietary choices link environmental sustainability and human health, 
showing that there are alternative dietary options that can improve both human and environmental health. Springmann et al. (2018) evaluate the possible benefits of different diets. They show that changes toward fewer animal- and more plant-based foods are associated with significant benefits due to reductions in diet-related mortality and greenhouse gases emissions. Similarly, Muller et al. (2017) analyze the role organic agriculture could play in sustainable food systems.

Changes in food consumption, for example, the proneness to consume more meat and dairy, lead to changes in production decisions and land allocation, which can impact the environment, in an increasingly resource-constrained world.

Clearly, producing more food to mitigate hunger may involve unwanted externalities, and certain types of diets can harm both human health and the environment. Thus, the analysis of food production patterns should consider the amount of energy as well as the diversity and the quality of the production basket.

Agricultural production of countries are relevant not only to ensure food but also to health and the environment. Therefore, the expected effect of concentration, diversification, and competitiveness of food production on sustainability depend on the trade-offs between increasing the quantity of food and improving the sustainability of food systems.

\section{Data and definitions}

\subsection{Agricultural data}

We use data from FAO (2019) on food production for the period 1993-2013, for 169 countries (Table A.1 of the Appendix), and of 219 agricultural goods (Table A. 2 of the Appendix). ${ }^{1}$

We define an agricultural or food product as any product or commodity, raw or processed, that is marketed for human consumption (excluding water, salt, and additives) or animal feed. FAO classifies agricultural products in four main groups: crops, crops processed, livestock primary, and livestock processed. ${ }^{2}$ All data are in tonnes. We also transform them into kilocalories (kcal), using the data provided by FAO (2001).

\subsection{Food supply and imports}

We use food balance sheets to obtain data on food supply at the country level (FAO, 2019). The food supply of a given country is determined by total production, plus imports, minus exports, stock variation, and the use of agricultural products for utilization different from food, such as animal feed, seeds, and others. We also consider imports of food given their relevance for food supply together with domestic production. Both food supply and imports data are given in kcal per capita per day, after applying appropriate food composition factors for all primary and processed products in terms of dietary energy value content.

\subsection{Food security and sustainability of food systems}

We employ a composite index, built by Caccavale \& Giuffrida (2020), that measures the multidimensional concept of food security, covering 185 countries between 1990 and 2017. The index weights 21 selected indicators distributed in the four pillars of food security: availability, access, utilization, and stability. It shows

\footnotetext{
1 The completeness of the data defines the period of the analysis. Before 1993 and after 2013, data at the product level are incomplete for several countries. Additionally, food balance sheets are available until 2013.

2 We exclude the production of live animals (in heads) because it cannot be compared with the rest of agricultural production. We also exclude fibers for textiles and other products for non-food uses.
}

robust results over time, which are comparable within and between countries, allowing tracking countries' progress towards food security. The measure ranges between 0 and 1 , with lower values indicating greater food security. We redefine the index to obtain a measure indicating that an increase in the score implies an improvement in food security (1 - index).

Additionally, we use an indicator of the sustainability of food systems from Béné et al. (2019b), which is computed for 97 countries every three years between 2000 and 2017. The authors refine an extensive list of indicators applying a rigorous inclusion/exclusion protocol and shorten it to 27 that are grouped in four dimensions: environmental, economic, social, and food and nutrition, which are aggregated into a composite indicator. The metric allows comparing levels of food systems sustainability between countries and over time. The data are available at Achicanoy et al. (2019).

Finally, we employ a set of indicators that quantify the status of national food systems performance of 156 countries in 2011, considering several dimensions of food security and the sustainability of food systems. Chaudhary et al. (2018) presents 25 sustainability indicators across seven domains: nutrition, environment, food affordability and availability, socio-cultural well-being, resilience, food safety, and food waste. They show that different countries have widely varying patterns of performance and unique priorities for improvement.

\section{Methodology}

\subsection{Agricultural product space and agricultural country space networks}

We define the agricultural production space (APS), which is represented, in each year $t$, by a bipartite $C \times P$ matrix $X^{t}$ where rows are the $C$ countries, columns are the $P$ products. Non-zero entries $X_{i k}^{t}$ represent whether country $i$ produces product $k$ in year $t$ (if production $Q_{i k t}$ is strictly larger than zero). Then, considering the revealed comparative advantages (RCA) of countries (Balassa, 1965), we determine the relevant producers for each product, and we get the RCA-based bipartite country-product matrix $Y$, with relevant producers only. This validation is essential because countries produce a wide variety of agricultural products making the APS very dense. With the RCA-based bipartite matrix $(Y)$, we compute the product-product and country-country relatedness, which we name the Agricultural Product Space Network and the Agricultural Country Space Network, accordingly. Finally, we detect communities in both networks.

In order to compute the RCA, we weight production using the agricultural gross production value (GPV) of countries, which is built by multiplying gross production in physical terms by output prices at the farm gate (in constant 2004-2006 million dollars) (FAO, 2019). We compute RCA as:

$$
R C A_{i k t}=\frac{Q_{i k t} / \sum_{j} Q_{j k t}}{G P V_{i t} / \sum_{j} G P V_{j t}},
$$

where $Q$ is production of product $k, i$ is a country, and $t$ is a given year. We assume that a $R C A_{i k t} \geqslant 1$ reveals that country $i$ is a relevant producer of product $k$ at time $t$. This approach has been used to measure different types of capabilities (for example: Hidalgoet al. (2007), Ferrarini \& Scaramozzino (2016), Petralia et al. (2017) and Bruno et al. (2018)).

Suppressing time subscripts for simplicity, the elements of the RCA-based bipartite matrix $(Y)$ are defined as: 
$y_{i k}= \begin{cases}0 & \text { if } R C A_{i k}<1, \\ 1 & \text { if } R C A_{i k} \geqslant 1\end{cases}$

The APS allows measuring the degree of relatedness between dyads of products and countries. Thus, we define the Agricultural Product Space Network (APSN) as a network-based representation of global agricultural production, where nodes are agricultural products, and ties among them indicate their degree of relatedness. Similarly, the Agricultural Country Space Network (ACSN), the degree of relatedness between a dyad of countries depends on the similarity of their production baskets. The relatedness measure allows quantifying the existence of a set of capabilities, including environmental conditions, technology, capital, institutions, and skills, which shape diversification patterns.

We use the Jaccard index as a measure of relatedness. In the product case, similarity $P$ between products $(k, k \prime)$ reads:

$P_{k k^{\prime}}=\frac{V_{k k^{\prime}}}{V_{k}+V_{k^{\prime}}-V_{k k^{\prime}}}$,

where $V_{k k^{\prime}}=\sum_{i} y_{i k} y_{i k \prime}$ is the number of times two different countries produce products $k$ and $k$ / together, and $V_{k}=\sum_{i} y_{i k}$ is the total number of countries that produce $k$. The resulting matrix $P$ is used to define the APSN, where nodes are products and weighted links $P_{k k}$ measure the similarity between them.

In the ACSN, nodes are countries and a link between countries $i$ and $i$ is weighted by the Jaccard index $C_{i i}$, which measures similarity between countries' production baskets. To compute the Jaccard index between countries, we replace $V_{k k \prime}$ and $V_{k}$ in Eq. (3) by $\Lambda_{i i \prime}=\sum_{k} y_{i k} y_{i / k}$ (the number of goods that are produced by countries $i$ and $i$, together) and $\Lambda_{i}=\sum_{k} y_{i k}$ (the total number of products produced by country $i$ ).

To detect communities in the APSN and the ACSN, we use the Louvain algorithm (Blondel et al., 2008). The algorithm optimizes a function known as "modularity" over the possible partitions of a network. Modularity aims to capture the degree to which a network can be partitioned into groups of nodes, with higher interaction within groups than between them. We use the weighted version of the Louvain algorithm to consider link weights in the APSN and the ACSN.

\subsection{Fitness and complexity}

The bipartite matrix $(Y)$ gathers valuable information on countries capabilities to produce diverse products. A simple way of measuring these capabilities is to count the total number of items produced. However, this strategy ignores that the production of some goods requires capabilities that may be unevenly distributed among countries and that some products are more or less complex to produce.

For a network representation of a complex system, there exist different algorithms to extract information on the nodes through their position, for example, centrality. ${ }^{3}$ In the APS, the role of countries is linked to their competitiveness -or to their ability to produce different products-, while the role of products is linked to their ease of production. Tacchella et al. (2012) provide an algorithm to reduce the multidimensional problem at analyzing the bipartite matrix of exported products and exporting countries. The authors achieve a measure of countries' competitiveness, which they call Fitness, and of the difficulty -in terms of required capabilities- of exporting a

\footnotetext{
3 There are several measures of centrality in a network (Borgatti, 2005). A wellknown example of determining the role of different actors in a network is the Google PageRank algorithm (Brin \& Page, 1988).

4 The methodology builds on the measure proposed by Hidalgo \& Hausmann (2009). Both measures have drawbacks that will be addressed when necessary in the analysis of the results.
}

given product, which they call Complexity. The method rewards countries according to the variety and complexity of their production baskets. ${ }^{4}$

We apply this algorithm to the RCA-based bipartite matrix. The fitness and complexity algorithm is a non-linear iterative approach that can efficiently capture the intrinsic link between different countries' production baskets and competitiveness. The iteration process couples the fitness of a country to the complexity of a product and then obtains the fixed point values. This result is achieved by exploiting the information in the binary matrix that represents each country's detailed production, combining measures on its rows and columns iteratively. At each iteration, fitness and complexity are renormalized to keep the total production and the average complexity of products constant. For more details on the methodology, see: Tacchella et al. (2012) and Pugliese et al. (2016).

\subsection{Econometric estimations}

Using evidence from the bipartite networks, we perform an econometric analysis to evaluate the effects of competitiveness (or fitness), concentration, and diversification of food production, on food supply, food security, and food systems sustainability at the country level.

We estimate the concentration of food production using the Shannon entropy index. We first transform the production of each good from tonnes into kcal to obtain a comparable measure, using the data on food supply reported in kcal. Next, for every country, we compute their production in kcal, and estimate the concentration of their production baskets. For a country $i$, with a production basket of agricultural goods $\Omega_{i t}$ in a given year $t$, the entropy index is defined as:

$S_{i t}=-\sum_{k \in \Omega_{i t}} s_{i k t} \ln s_{i k t}$,

where $s_{i k t}$ is the share of the $k$ variety in the production basket. An increase in the index indicates a decrease in the concentration of production.

Besides, we define a variable that measures the overall similarity of the production baskets of countries. The fact that a country produces several products does not necessarily mean that all those products are strongly connected in the APSN because diversification can occur in different ways. Most likely, diversification is expected in products close to those already produced. However, countries may also build capabilities to develop new products that are far from the capabilities revealed in the products currently produced. However, this is less likely to occur as the possibilities of diversification into new products are strongly determined by the set of current capabilities.

An indicator of the "coherence" of the diversification process allows us to explore whether countries diversify in products that are close to their set of current capabilities or if, conversely, they diversify in products that are far from their revealed capabilities. For a given country, we define the coherence of its production basket as the total strength of the products in the APSN:

Coherence $_{i t}=\sum_{k \in \Omega_{i t}^{*}} \sum_{k \in \Omega_{i t}^{*}} P_{k k t t}$,

where $\Omega_{i t}^{*}$ is the production basket of country $i$ restricted to those products $k$ with $R C A_{i k t} \geqslant 1$ at time $t$. Given that the APSN is very dense, the measure of coherence has very large values. Therefore, we express it in thousands.

We estimate the following benchmark model:

$y_{i t}=\beta_{0}+\beta_{1} Z_{i t}+\beta_{2} X_{i t}+\alpha_{i}+\tau_{t}+\mu_{i t}$, 
where $y$ is either: (i) food supply per capita per day in calories, (ii) an indicator of food security, or (iii) an index of the sustainability of food systems, in a given year $t ; Z$ are different variables related to specialization patterns in food production: the index of concentration of agricultural production, the entropy index (Entropy), the indicator of the coherence of the agricultural production baskets (Coherence), and fitness, the indicator of countries capabilities or competitiveness (Fitness). $X$ includes a set of control variables: agricultural total factor productivity (Agr.TFP); human capital (HumanCapital), as an indicator of the development level of countries; imports per capita per day in calories (Imports); the latitude of countries in absolute values (Latitude), as an indicator of climatic characteristics and biodiversity; a dummy indicating whether countries belong to the more developed community detected in the ACSN (Community); and a set of dummies indicating the geographical regions of countries. Finally, $\alpha$ are country fixed effects, $\tau$ are time dummies, and $\mu$ are the residuals.

In some specifications, we analyze possible different effects on the communities of countries detected in the ACSN. In these estimations, we fix community membership for each country the whole period by the mode, i.e., we assign each country the community in which it was most frequently detected. The reason is that a very low number of countries, in general, those in the border of the communities, appear in different communities in different years (for a detailed analysis of the stability of the communities, see: Campi et al. (2020)).

Table A.3 in the Appendix describes the variables and their sources, and Table A.4 reports the summary statistics. Fig. A.1 in the Appendix shows the distribution of the entropy index and the coherence of diversification patterns.

We adopt different strategies to estimate Eq. (6) to check the robustness of the results. Firstly, we use a pooled ordinary least squares (OLS) estimation method because the dependent variables are relatively invariant over the years considered and have a relatively low variation across countries. Besides, pooled OLS estimations allow us to consider the effect of relevant time-invariant variables on geographical conditions. Secondly, we use a panel data fixed effects (FE) estimation method, which is expected to control unobserved heterogeneity and omitted variables bias better.

These estimations might be affected by the endogeneity of the measures related to food production specialization, which could lead to biased results. Fitness, concentration, and coherence could be correlated with the error term due to unobserved heterogeneity or omitted variables, confounding both independent and dependent variables. For example, countries could implement policies driving to different specialization patterns if their food supply levels or food security are not satisfactory and if they want to achieve sustainability.

However, policies seeking to change production systems might take a considerable time to be effective because there are severe restrictions (including environmental) to increase production and radically change specialization patterns in the short run. Besides, although the measures that characterize food production partly result from countries' individual production decisions, they are also likely to be affected by exogenous events, for example, by changes in international food prices that do not depend on the decisions of an individual country. Therefore, both concentration and coherence could be exogenous in the short- and mediumterm and the result of the interaction of food-producing countries at the international level. In the case of fitness, the measure is partly determined by the revealed capabilities of countries. However, it is also the result of the empirical ranking derived from the ACSN, which is determined by the behavior of all foodproducing countries.

Nevertheless, we econometrically test the presence of endogeneity in these variables with commonly employed instrumental variables techniques on the pooled and panel data. In both cases, we use as instruments the one-year lags of the potentially endogenous variables: entropy, coherence, and fitness. ${ }^{5}$

\section{Results}

5.1. The agricultural product space and the agricultural country space networks

Fig. 1 shows the Agricultural Product Space Network (APSN) and the Agricultural Country Space Network (ACSN) in 2013. Nodes are products/countries, and links represent the RCA-based bipartite country-product matrix projection into a between product/country similarity measure computed with the Jaccard index.

Both networks are very dense, meaning that many products are jointly produced in the APSN, and that many countries can produce a relatively large number of similar products in the ACSN. The reason is that most countries share capabilities to produce a basket of common food products, including eggs, some types of meat, dairy products, and fruits. Besides, in some cases, the cost of moving fragile products such as eggs, fresh products, such as milk, or perishable fruits from one country to another, could explain the ubiquity in their production.

Both networks are fully-connected, but despite their high density, products and countries cluster in well-defined communities. In the APSN, this implies that products that belong to a given community need similar production capabilities. In the ACSN, countries within a community are characterized by relatively similar endowments of environmental conditions and capabilities for agricultural production. Both products and countries within a community have higher interaction within them than with products and countries in other communities.

In the APSN, we observe four communities portrayed in different colors in Fig. 1. The purple community includes mainly tropical fruits and crops, such as mangoes, bananas, coconuts, avocados, and coffee. In blue, we observe crops, such as wheat and barley, processed crops, and processed livestock products, such as butter and cheese. In the green community, most products are vegetables, nuts, and fruits from Mediterranean or sub-tropical regions. The orange community mostly groups products with a low relevance in global food production and consumption, such as quinoa, Brazil nuts, safflower seeds and oil, camelids and rodents meat, and mate, a plant used in a traditional South American infused drink.

In the ACSN, we detect two well-defined communities of great size. Interestingly, one community (in blue) groups most highincome countries and a group of middle-income countries that have relatively developed agricultural systems, such as Uruguay, Argentina, and several Eastern European countries. ${ }^{6}$ Instead, the other community (in red) mostly groups middle- and low-income countries, and a few high-income countries, which are mainly small islands, such as Bahamas, Barbados, Hong Kong, French Polynesia, and New Caledonia. We name these communities as: "More Developed Community" (blue) and "Less Developed Community" (red). Table 1 shows several statistics of the two communities detected in the ACSN for 1993, 2003, and 2013.

We observe that, although the shares of the total population are similar in both communities, the shares of total production - in calories, proteins, and fats - are lower in the less developed com-

\footnotetext{
${ }^{5}$ We have also implemented system-GMM estimations (Arellano \& Bover, 1995; Blundell \& Bond, 1998) to further check the robustness of the results reported in the paper. The results of these estimations are available upon request.

${ }^{6}$ We classify countries by their income levels in 2010, using data from the World Bank. Classifications using income levels in other years do not modify the results. See: https://datahelpdesk.worldbank.org/knowledgebase/articles/906519-world-bankcountry-and-lending-groups. See Table A.1 in the Appendix.
} 

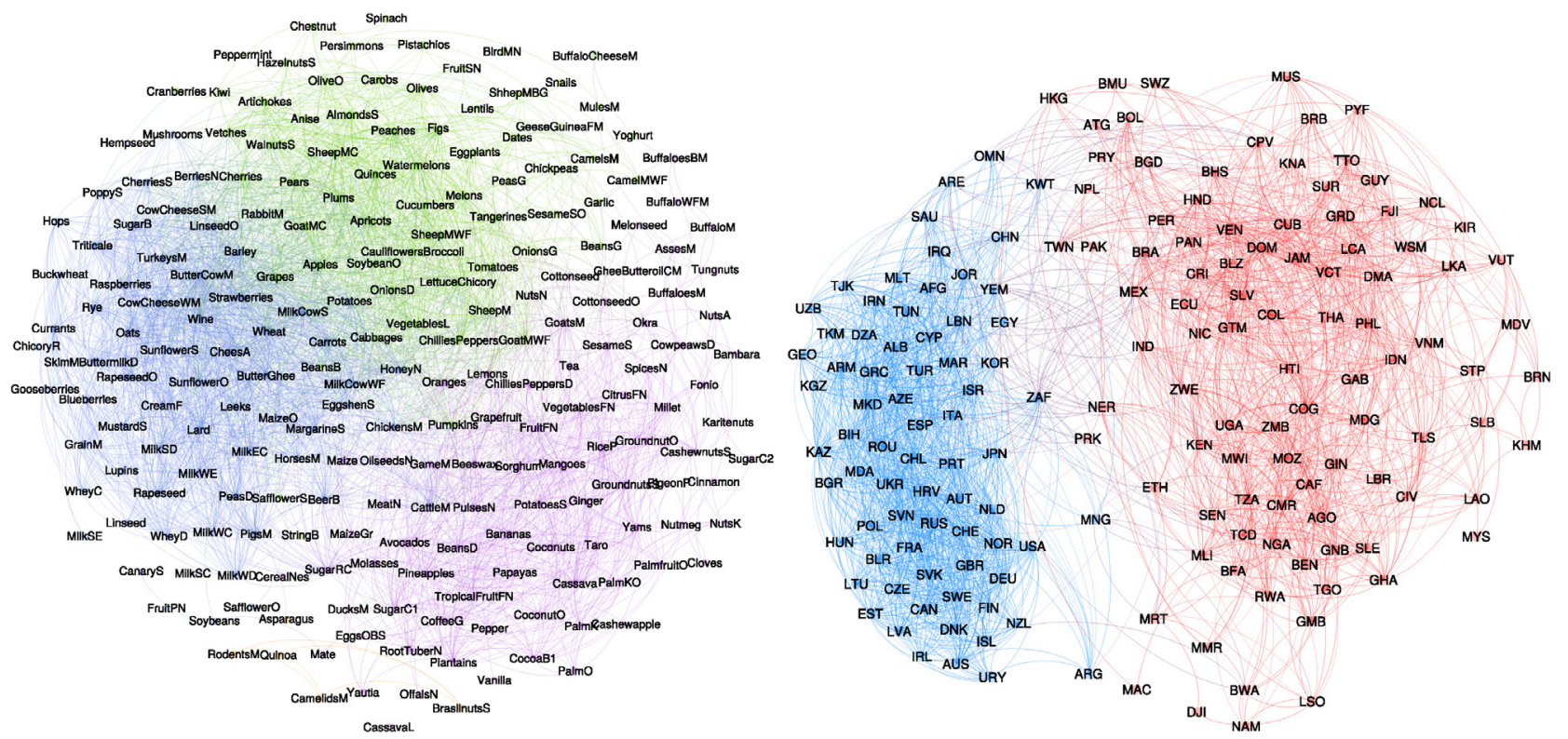

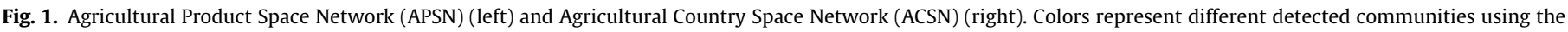

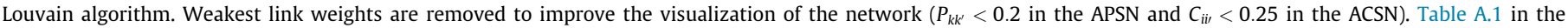
Appendix defines the ISO codes and Table A.2 present the list of products.

Table 1

Summary statistics of the communities detected in the ACSN. 1993, 2003, and 2013.

\begin{tabular}{|c|c|c|c|c|c|c|}
\hline & \multicolumn{2}{|c|}{1993} & \multicolumn{2}{|c|}{2003} & \multicolumn{2}{|c|}{2013} \\
\hline & $\begin{array}{c}\text { More Developed } \\
\text { (Blue) }\end{array}$ & $\begin{array}{l}\text { Less Developed } \\
\text { (Red) }\end{array}$ & $\begin{array}{l}\text { More Developed } \\
\text { (Blue) }\end{array}$ & $\begin{array}{l}\text { Less Developed } \\
\text { (Red) }\end{array}$ & $\begin{array}{c}\text { More Developed } \\
\text { (Blue) }\end{array}$ & $\begin{array}{c}\text { Less Developed } \\
\text { (Red) }\end{array}$ \\
\hline Number of countries & 75 & 94 & 75 & 94 & 73 & 96 \\
\hline Number of HIC & 37 & 9 & 37 & 9 & 36 & 10 \\
\hline Number of MIC & 34 & 59 & 34 & 59 & 33 & 60 \\
\hline Number of LIC & 4 & 26 & 4 & 26 & 4 & 26 \\
\hline Share of total population & 0.56 & 0.44 & 0.51 & 0.49 & 0.48 & 0.52 \\
\hline Share of total production in calories & 0.67 & 0.33 & 0.60 & 0.40 & 0.57 & 0.43 \\
\hline Share of total production in proteins & 0.75 & 0.25 & 0.69 & 0.31 & 0.67 & 0.33 \\
\hline Share of total production in fats & 0.63 & 0.37 & 0.56 & 0.44 & 0.51 & 0.49 \\
\hline Share of total food exports & 0.79 & 0.21 & 0.69 & 0.31 & 0.62 & 0.38 \\
\hline Share of total food imports & 0.77 & 0.23 & 0.70 & 0.30 & 0.72 & 0.28 \\
\hline
\end{tabular}

Notes: HIC: high-income countries, MIC: middle-income countries, LIC: low-income countries.

munity (red). Instead, the more developed community (blue) has higher production shares in all the measures considered. Moreover, the more developed community concentrates much higher shares of both total food exports and imports.

The architectures of the APSN and the ACSN are relatively stable for 1993-2013, which is a piece of interesting evidence given that the global food system has suffered unprecedented pressure and changes during this period. This relative stability indicates that although countries can and do change their production by acquiring new capabilities, countries can be consistently classified by their production baskets and their revealed capabilities. Besides, there is a persistent gap in production patterns that characterizes the network structure.

\subsection{Competitiveness of countries and sophistication of products}

Next, we apply the fitness and complexity algorithm to the bipartite matrix of world agricultural production. Fig. 2 shows a plot of the bipartite matrix in 2013, as defined in Eq. (2). In this graphical representation, countries are ordered by their competitiveness and products by their sophistication, which means that we have organized the rows in ascending order according to coun- tries fitness, and columns, from left to right, in ascending order of products complexity. Organized by the measures of fitness and complexity, the matrix reveals a triangular form, which might indicate nestedness in agricultural production.

Interestingly, but to some degree expected, the complexity or sophistication of products is not only related to the availability of technology, institutions, capital, and skills, but also to the presence of specific environmental conditions. For example, it is not surprising that products such as camelids and quinoa are classified as highly complex or more sophisticated, considering that they are produced in the "Puna", an ecosystem of a few South American countries (Argentina, Bolivia, Ecuador, and Peru). Camelids meat is only produced with a revealed comparative advantage by Bolivia and Peru, and quinoa by Bolivia, Ecuador, and Peru. A similar argument might apply for some other products classified as complex.

This evidence highlights the relevance of considering the role of agroecological conditions and other types of capabilities as determinants of RCA in agricultural production. It also calls attention to a feature of the indicator of fitness and complexity, pointed out by Morrison et al. (2017). This measure often highlights economies producing "exclusive niche products", which are not 


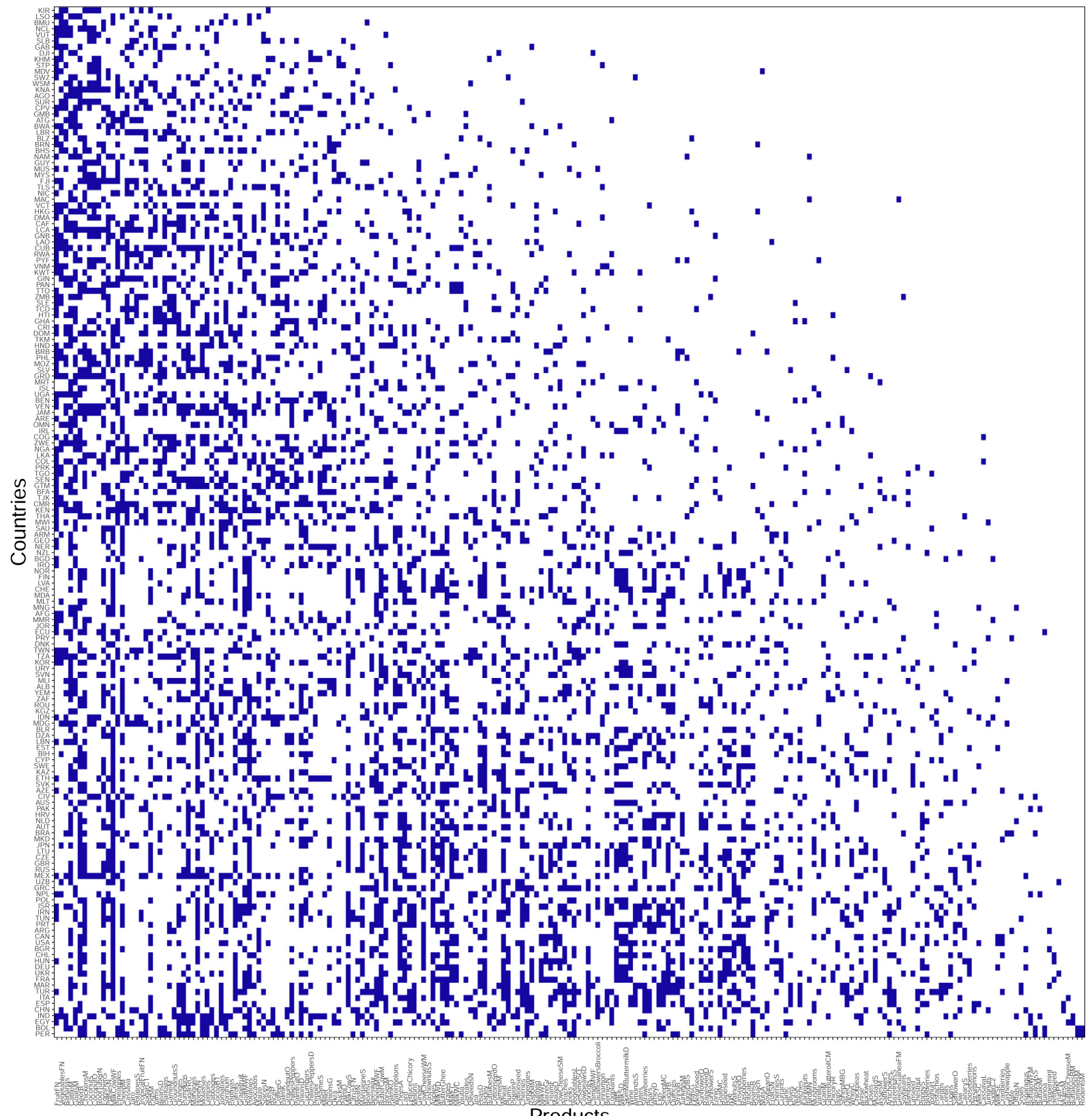

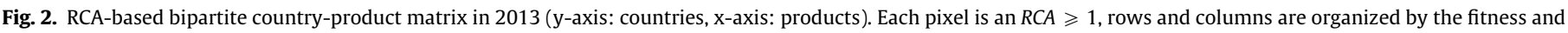
complexity algorithm.

necessarily the most complex or more sophisticated in terms of required capabilities. In the case of exports, the authors show that products that are classified as the most complex often tend to be sufficiently irrelevant to be exported by only a few countries. Thus, they claim that complexity is often difficult to interpret at the micro-level of products, suggesting that the indicators might be difficult to compare across different aggregation levels.

In the agricultural production space, we observe that some complex products and some countries with high fitness are not relevant in terms of global agricultural production, which might be caused by the existence of exclusive niche products. Thus, we reestimated the indicators of fitness and complexity excluding the products that can be considered as exclusive niche products. As expected, the fitness of countries producing those products decreases, but the scores and positions of the other countries remain broadly similar, indicating that the measure of fitness is robust to changes in the set of products considered. ${ }^{7}$ Given that scarce environmental conditions should also be considered within the set of capabilities necessary for agricultural production, we keep these probable exclusive niche products that turn out as sophisticated because they reflect that only a few countries have the environmental conditions necessary to produce them.

Given that fitness can be regarded as an indicator of competitiveness in food production, we expect it to be positively correlated with other macro indicators of competitiveness. Fig. 3 shows the dispersion diagram between fitness and: Gross Domestic Product (GDP), Agricultural Gross Production Value (GPV), and Agricultural Exports for 2013. The correlations are statistically significant and positive: 0.69 with GDP, 0.71 with GPV, and 0.64 with agricultural exports. Interestingly, we observe that those countries classified as 

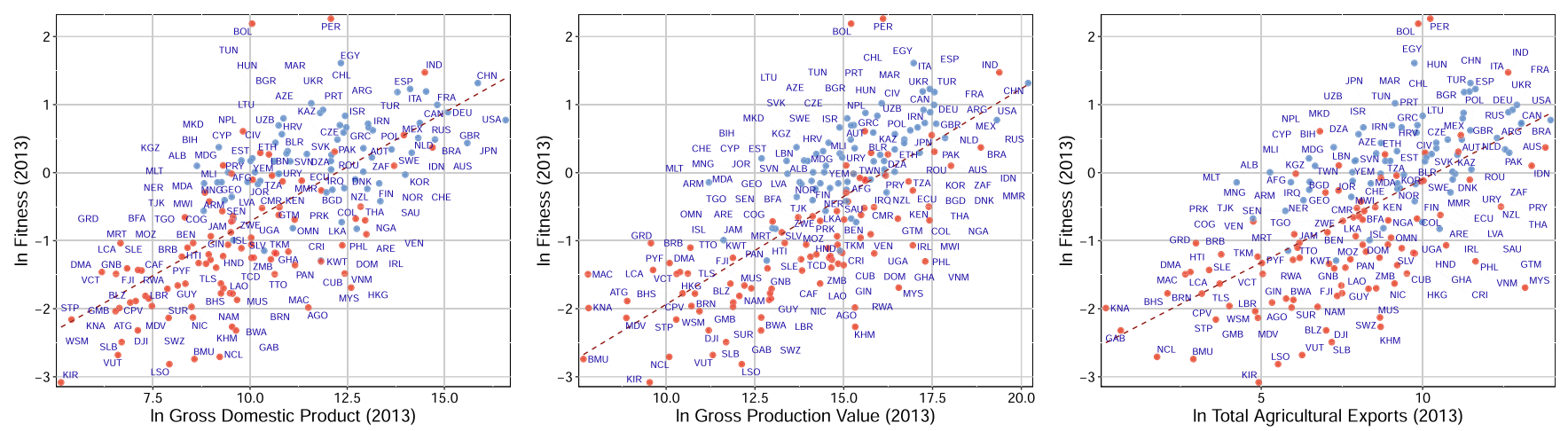

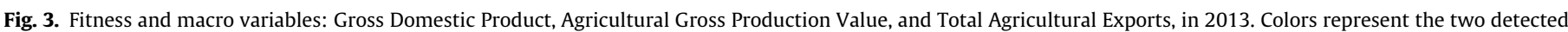
communities in the ACSN as in Fig. 1.

highly competitive because they produce exclusive niche products, such as Peru, Bolivia, and Egypt, appear as outliers in the dispersion diagrams.

Besides, by capturing capabilities and environmental endowments for food production, fitness is expected to have a positive correlation with food security. Instead, the correlation with the sustainability of food systems depends on the result of the tradeoff that can emerge when increasing food production and improving sustainability. Moreover, sustainability and food security are multidimensional concepts that might mask complex effects and relationships. Fig. 4 shows the correlations between fitness and several dimensions of food security and the sustainability of food systems from Chaudhary et al. (2018) for 2011.

We observe a positive correlation between fitness and food availability and affordability, food safety, food nutrient adequacy, resilience, and sociocultural well-being. Instead, we observe a negative correlation between fitness and food waste. In the cases of food affordability and availability, food safety, resilience, and sociocultural well-being, the scores of countries in the more developed community are higher than those of countries in the less developed community. This feature is less evident in food nutrient adequacy and food waste, which is in line with the evidence presented by Chaudhary et al. (2018) who show that high-income nations score well on most indicators, but poorly on environmental, food waste, and health-sensitive nutrient-intake indicators.

Finally, Fig. 5 presents the correlations between fitness and food supply, and two multidimensional measures of food security and food systems sustainability. We observe that fitness correlates positively with all these variables and that countries of the more developed community, in general, present better scores in all three indicators.

Overall, fitness seems able to reasonably capture the set of capabilities and environmental endowments that are needed for agricultural production. Besides, the presence of niche products at the micro level does not seem to undermine the behavior of fitness at the macro level. Despite there is high dispersion in some of the indicators considered, the correlations suggest that countries with higher fitness are better in terms of food security and sustainability of their food systems. Finally, the correlations show that one community includes countries with better scores in most indicators compared to countries in the other community, reflecting large differences between countries trajectories of agricultural development.

\subsection{The impact of country specialization patterns}

Tables 2-4 show the estimation results of Eq. (6) using food supply, food security, and sustainability of food systems, as the dependent variable, respectively, and different estimation methods, pooled OLS (POLS, models 1-3), pooled OLS with instrumental variables (IV POLS, models 4-6), fixed effects (FE, models 7-9), and fixed effects with instrumental variables (IV FE, models 10-12). Our variables of interest are entropy that measures concentration, coherence, which measures how countries diversify their production baskets, and fitness, which is a measure of competitiveness.

In Table 2, all estimation methods provide similar results. We find that increasing concentration in agricultural production has a negative effect on daily per capita food supply, while a coherent diversification of the production baskets positively affects food supply. This result indicates that countries exploit economies of scope to contribute to their food supply. Diversifying in products requiring capabilities that are close to those that countries already have, increases food supply. Fitness also has a positive effect on food supply, which implies that more competitive countries are able to produce more food.

The control variables have the expected signs and turn out significant in most cases. Agricultural total factor productivity, human capital, and per capita food imports have positive effects on food supply. Thus, countries that are more developed, with more productive agricultural systems, and can import more food per capita, have higher food supplies. The latitude of countries in absolute values, which proxies environmental conditions, is statistically significant and positive. Also, the dummy indicating if a country belongs to the more developed community, shows that countries in this community are relatively better in terms of food supply than countries in the less developed community.

In the instrumental variables estimations, the partial F-tests confirm that the instruments are strong. However, the endogeneity tests reveal that only fitness should be treated as endogenous (models 6 and 12), while entropy and coherence can be treated as exogenous (models 4, 5, 10, and 11). Thus, in the latter cases, pooled OLS or FE estimations provide more reliable results. The significance and magnitude of the estimated coefficient are similar in all models.

Table 3 presents the estimation results with food security as the dependent variable. We estimate that concentrating production has a negative effect on food security and that a coherent diversification positively affects food security. The effect of competitiveness is positive when it turns out significant. Thus, the estimated effects on food security are similar to those estimated in the case of food supply, although their significance is weaker in some cases.

The control variables have the expected signs when they turn out statistically significant. The dummy indicating if a country belongs to the more developed community is positive and statistically significant in all the estimations, implying that countries in this community are relatively better in terms of food security than countries in the less developed community. 

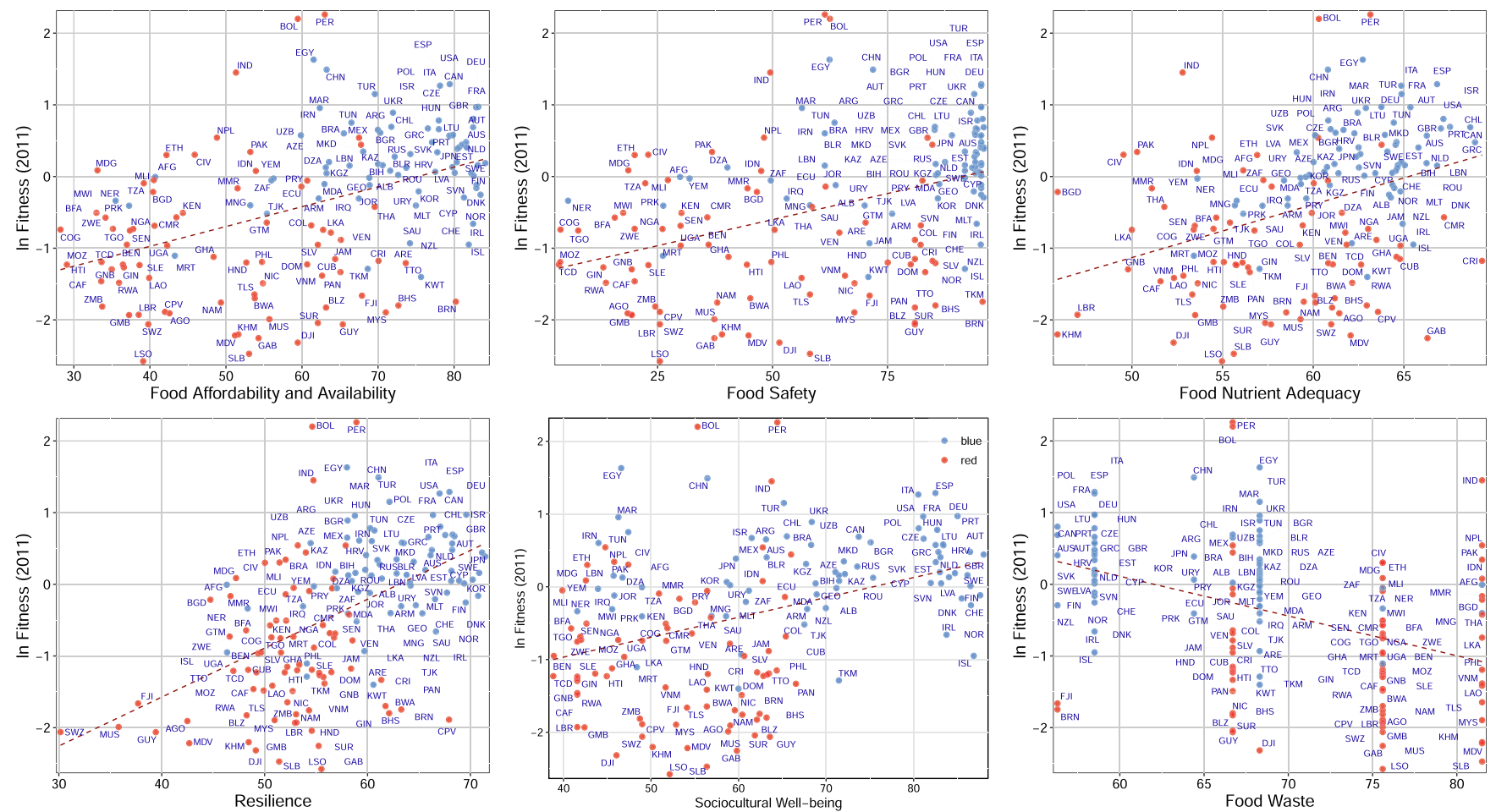

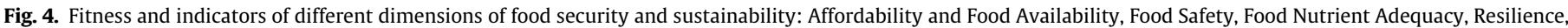
Sociocultural Well-being, and Food Waste, in 2011. Colors represent the two detected communities in the ACSN as in Fig. 1.
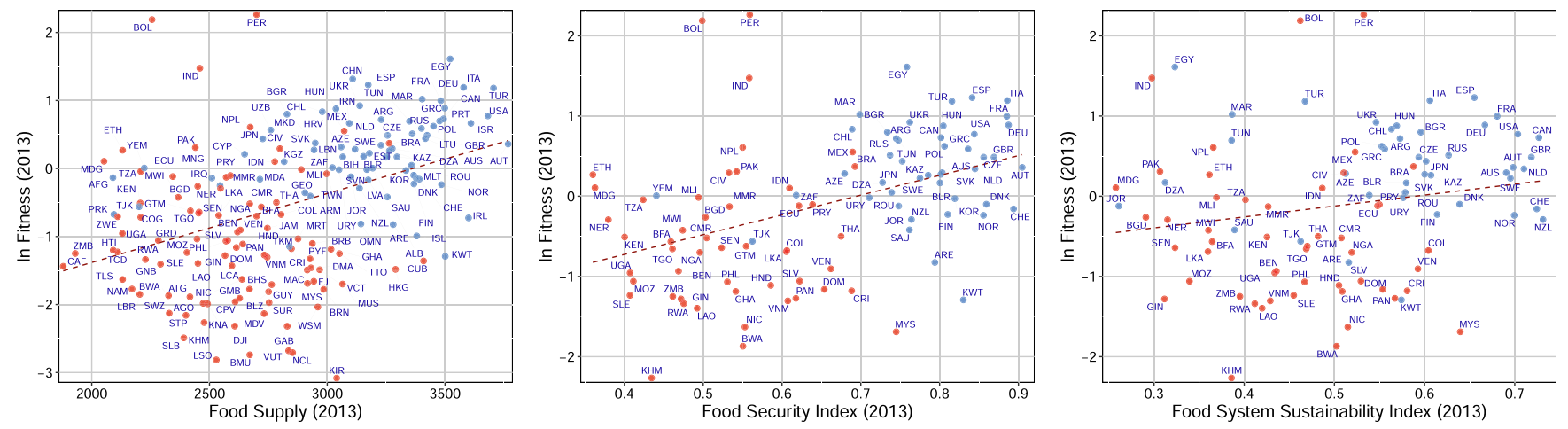

Fig. 5. Fitness and: food supply, food security, and sustainability of food systems, in 2013 . Colors represent the two detected communities in the ACSN as in Fig. 1.

Interestingly, in the instrumental variables estimations, the endogeneity tests suggest that all potentially endogenous variables can be treated as exogenous. Therefore, when we use food security as the dependent variable, pooled OLS and FE estimation methods are preferred and are expected to provide more reliable results.

Table 4 presents the estimation results using the index of sustainability of food systems as the dependent variable. We estimate that concentrating production has a negative effect on sustainability, although the estimated coefficients are not statistically significant in some models. In contrast with the previous estimations, a coherent diversification, this is, in products that are close to countries capabilities, might have a negative effect on food systems sustainability. Similarly, fitness has a negative impact on sustainability, although not statistically significant in most models. This result might be explained by the trade-off between increasing agricultural production and achieving more sustainable food systems. In general, the control variables have the expected signs when they turn out significant. Interestingly, countries in the more developed community are better in terms of sustainability of their food systems.

The instrumental variables estimations indicate that production specialization variables can be treated as exogenous in models 5,6 , and 12 while they should be treated as endogenous in models 4 , 10 , and 11 . In the latter cases, instrumental variables estimations are preferred. However, in models 10 and 12, the partial F-tests for instrumental variables report that the instruments are weak, which is probably related to the fact that the index is only available for five years and a lower number of countries.

Considering all the estimations with different dependent variables, the dummies for geographical regions are, in several cases, statistically significant. We use East Asia \& Pacific as the base region (see Table A. 1 in the Appendix). Belonging to regions that include richer countries than the base positively impacts food supply and food security (North America and Europe \& Central Asia). We observe the opposite for regions with a lower GDP per capita on average (South Asia and Sub-Saharan Africa). The estimated 
Table 2

The effect of country specialization patterns on per capita food supply.

\begin{tabular}{|c|c|c|c|c|c|c|c|c|c|c|c|c|}
\hline \multirow{2}{*}{$\begin{array}{l}\text { Dependent variable } \\
\text { Model }\end{array}$} & \multicolumn{3}{|c|}{ POLS } & \multicolumn{3}{|c|}{ IV POLS } & \multicolumn{3}{|c|}{ FE } & \multicolumn{3}{|c|}{ IV FE } \\
\hline & (1) & (2) & (3) & (4) & (5) & (6) & (7) & $(8)$ & (9) & (10) & (11) & (12) \\
\hline Entropy & $\begin{array}{c}0.117^{* * * *} \\
(0.012)\end{array}$ & & & $\begin{array}{c}0.115^{* * *} \\
(0.013)\end{array}$ & & & $\begin{array}{c}0.110^{* * * *} \\
(0.041)\end{array}$ & & & $\begin{array}{c}0.129^{* * *} \\
(0.029)\end{array}$ & & \\
\hline Coherence & & $\begin{array}{l}0.292^{* * *} \\
(0.024)\end{array}$ & & & $\begin{array}{c}0.289 * * * \\
(0.024)\end{array}$ & & & $\begin{array}{c}0.220^{* * *} \\
(0.057)\end{array}$ & & & $\begin{array}{c}0.264^{* * *} \\
(0.042)\end{array}$ & \\
\hline Fitness (ln) & & & $\begin{array}{l}0.109^{* * *} \\
(0.010)\end{array}$ & & & $\begin{array}{l}0.110^{* * *} \\
(0.011)\end{array}$ & & & $\begin{array}{c}0.095^{* * *} \\
(0.030)\end{array}$ & & & $\begin{array}{c}0.132^{* * *} \\
(0.019)\end{array}$ \\
\hline Agr. TFP (ln) & $\begin{array}{c}0.278^{* * *} \\
(0.052)\end{array}$ & $\begin{array}{l}0.281^{* * *} \\
(0.050)\end{array}$ & $\begin{array}{l}0.242^{* * *} \\
(0.050)\end{array}$ & $\begin{array}{l}0.356^{* * *} \\
(0.042)\end{array}$ & $\begin{array}{l}0.335^{* * *} \\
(0.039)\end{array}$ & $\begin{array}{l}0.303^{* * *} \\
(0.040)\end{array}$ & $\begin{array}{c}0.350^{* * *} \\
(0.059)\end{array}$ & $\begin{array}{c}0.344^{* * *} \\
(0.058)\end{array}$ & $\begin{array}{c}0.347^{* * *} \\
(0.058)\end{array}$ & $\begin{array}{l}0.340^{* * *} \\
(0.023)\end{array}$ & $\begin{array}{l}0.331^{* * *} \\
(0.021)\end{array}$ & $\begin{array}{l}0.336^{* * *} \\
(0.022)\end{array}$ \\
\hline Human Capital & $\begin{array}{l}0.089^{* * *} \\
(0.018)\end{array}$ & $\begin{array}{l}0.097^{* * *} \\
(0.017)\end{array}$ & $\begin{array}{l}0.098^{* * *} \\
(0.017)\end{array}$ & $\begin{array}{l}0.095^{* * *} \\
(0.018)\end{array}$ & $\begin{array}{l}0.100^{* * *} \\
(0.017)\end{array}$ & $\begin{array}{l}0.101^{* * *} \\
(0.017)\end{array}$ & $\begin{array}{c}0.198^{* * *} \\
(0.054)\end{array}$ & $\begin{array}{l}0.198^{* * *} \\
(0.053)\end{array}$ & $\begin{array}{l}0.203^{* * *} \\
(0.052)\end{array}$ & $\begin{array}{l}0.202^{* * *} \\
(0.022)\end{array}$ & $\begin{array}{l}0.208^{* * *} \\
(0.021)\end{array}$ & $\begin{array}{l}0.208^{* * *} \\
(0.021)\end{array}$ \\
\hline Imports (ln) & $\begin{array}{l}0.133^{* * *} \\
(0.007)\end{array}$ & $\begin{array}{c}0.148^{* * *} \\
(0.007)\end{array}$ & $\begin{array}{l}0.166^{* * *} \\
(0.007)\end{array}$ & $\begin{array}{l}0.136^{* * *} \\
(0.007)\end{array}$ & $\begin{array}{l}0.151^{* * *} \\
(0.007)\end{array}$ & $\begin{array}{l}0.169^{* * *} \\
(0.008)\end{array}$ & $\begin{array}{c}0.104^{* * *} \\
(0.016)\end{array}$ & $\begin{array}{l}0.102^{* * *} \\
(0.015)\end{array}$ & $\begin{array}{l}0.105^{* * *} \\
(0.015)\end{array}$ & $\begin{array}{l}0.104^{* * *} \\
(0.007)\end{array}$ & $\begin{array}{l}0.102^{* * *} \\
(0.007)\end{array}$ & $\begin{array}{l}0.107^{* * *} \\
(0.007)\end{array}$ \\
\hline Latitude (Abs. Value) & $\begin{array}{c}0.004^{* * * *} \\
(0.001)\end{array}$ & $\begin{array}{c}0.004^{* * * *} \\
(0.001)\end{array}$ & $\begin{array}{c}0.003^{* * *} \\
(0.001)\end{array}$ & $\begin{array}{c}0.004^{* * *} \\
(0.001)\end{array}$ & $\begin{array}{c}0.004^{* * * *} \\
(0.001)\end{array}$ & $\begin{array}{c}0.003^{* * * *} \\
(0.001)\end{array}$ & & & & & & \\
\hline Community & $\begin{array}{l}0.199^{* * *} \\
(0.035)\end{array}$ & $\begin{array}{l}0.119 * * * \\
(0.035)\end{array}$ & $\begin{array}{l}0.108^{* * *} \\
(0.038)\end{array}$ & $\begin{array}{l}0.197^{* * *} \\
(0.035)\end{array}$ & $\begin{array}{l}0.118^{* * *} \\
(0.036)\end{array}$ & $\begin{array}{l}0.105^{* * *} \\
(0.039)\end{array}$ & & & & & & \\
\hline Europe \& Central Asia & $\begin{array}{c}0.031 \\
(0.031)\end{array}$ & $\begin{array}{l}-0.021 \\
(0.030)\end{array}$ & $\begin{array}{c}0.048^{*} \\
(0.028)\end{array}$ & $\begin{array}{c}0.030 \\
(0.031)\end{array}$ & $\begin{array}{c}-0.022 \\
(0.030)\end{array}$ & $\begin{array}{c}0.047^{*} \\
(0.029)\end{array}$ & & & & & & \\
\hline Latin America \& Caribbean & $\begin{array}{c}-0.101^{* * *} \\
(0.020)\end{array}$ & $\begin{array}{c}-0.084^{* * *} \\
(0.020)\end{array}$ & $\begin{array}{c}-0.086^{* * *} \\
(0.018)\end{array}$ & $\begin{array}{l}-0.101^{* * *} \\
(0.021)\end{array}$ & $\begin{array}{c}-0.085^{* * *} \\
(0.020)\end{array}$ & $\begin{array}{c}-0.087^{* * * *} \\
(0.018)\end{array}$ & & & & & & \\
\hline Middle East \& North Africa & $\begin{array}{c}0.043 \\
(0.034)\end{array}$ & $\begin{array}{c}0.007 \\
(0.033)\end{array}$ & $\begin{array}{c}0.051 \\
(0.032)\end{array}$ & $\begin{array}{c}0.050 \\
(0.034)\end{array}$ & $\begin{array}{c}0.013 \\
(0.033)\end{array}$ & $\begin{array}{c}0.057^{*} \\
(0.033)\end{array}$ & & & & & & \\
\hline North America & $\begin{array}{c}0.529^{* * * *} \\
(0.044)\end{array}$ & $\begin{array}{c}0.449^{* * *} \\
(0.041)\end{array}$ & $\begin{array}{c}0.449^{* * *} \\
(0.043)\end{array}$ & $\begin{array}{c}0.534^{* * *} \\
(0.044)\end{array}$ & $\begin{array}{c}0.454^{* * *} \\
(0.041)\end{array}$ & $\begin{array}{c}0.454^{* * *} \\
(0.042)\end{array}$ & & & & & & \\
\hline South Asia & $\begin{array}{c}-0.073^{* * *} \\
(0.019)\end{array}$ & $\begin{array}{c}-0.100^{* * *} \\
(0.019)\end{array}$ & $\begin{array}{c}-0.159^{* * *} \\
(0.022)\end{array}$ & $\begin{array}{l}-0.066^{* * *} \\
(0.020)\end{array}$ & $\begin{array}{c}-0.095^{* * *} \\
(0.020)\end{array}$ & $\begin{array}{l}-0.154^{* * * *} \\
(0.023)\end{array}$ & & & & & & \\
\hline Sub-Saharan Africa & $\begin{array}{c}-0.164^{* * *} \\
(0.021)\end{array}$ & $\begin{array}{c}-0.108^{* * *} \\
(0.018)\end{array}$ & $\begin{array}{c}-0.094^{* * *} \\
(0.019)\end{array}$ & $\begin{array}{c}-0.156^{* * *} \\
(0.021)\end{array}$ & $\begin{array}{l}-0.102^{* * *} \\
(0.019)\end{array}$ & $\begin{array}{c}-0.087^{* * * *} \\
(0.019)\end{array}$ & & & & & & \\
\hline Observations & 2,728 & 2,728 & 2,728 & 2,600 & 2,600 & 2,600 & 2,728 & 2,728 & 2,728 & 2,600 & 2,600 & 2,600 \\
\hline $\begin{array}{l}\text { R-squared } \\
\text { Number of countries }\end{array}$ & 0.669 & 0.686 & 0.685 & 0.669 & 0.687 & 0.686 & $\begin{array}{c}0.499 \\
130\end{array}$ & $\begin{array}{c}0.501 \\
130\end{array}$ & $\begin{array}{c}0.500 \\
130\end{array}$ & $\begin{array}{c}0.496 \\
130\end{array}$ & $\begin{array}{c}0.500 \\
130\end{array}$ & $\begin{array}{c}0.494 \\
130\end{array}$ \\
\hline Dependent variables & & & & & & First stage & & & & & & \\
\hline Entropy Index ${ }_{t-1}$ & & & & $\begin{array}{l}0.958^{* * *} \\
(0.006)\end{array}$ & & & & & & $\begin{array}{l}0.556^{* * *} \\
(0.016)\end{array}$ & & \\
\hline Coherence $_{t-1}$ & & & & & $\begin{array}{c}0.978 * * * \\
(0.004)\end{array}$ & & & & & & $\begin{array}{c}0.681^{* * *} \\
(0.014)\end{array}$ & \\
\hline Fitness $_{t-1}(\ln )$ & & & & & & $\begin{array}{l}0.982^{* * *} \\
(0.003)\end{array}$ & & & & & & $\begin{array}{l}0.675^{* * *} \\
(0.014)\end{array}$ \\
\hline Partial F-test of IVs & & & & 28540.13 & 67717.46 & 94198.93 & & & & 1137.22 & 2224.7 & 2318.03 \\
\hline p-value & & & & 0.000 & 0.000 & 0.000 & & & & 0.000 & 0.000 & 0.000 \\
\hline Endogeneity test & & & & 1.464 & 0.568 & 3.837 & & & & 2.199 & 3.582 & 16.103 \\
\hline $\mathrm{p}$-value & & & & 0.226 & 0.451 & 0.050 & & & & 0.138 & 0.058 & 0.000 \\
\hline
\end{tabular}

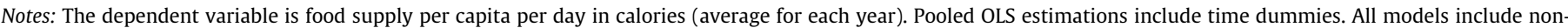

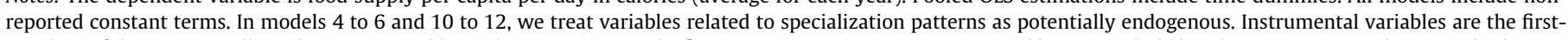

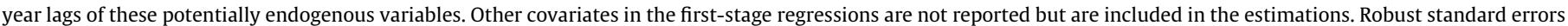
are in parentheses. Significance level: ${ }^{* * *} \mathrm{p}<0.01,{ }^{* *} \mathrm{p}<0.05,{ }^{*} \mathrm{p}<0.10$.

effects for regions with GDP per capita close to the base region (Middle East \& North Africa and Latin American \& the Caribbean) can be positive or negative. In the case of food systems sustainability, the effect of geographical regions also seems to be related to their average GDP per capita. The estimated effect is negative for Middle East \& North Africa, South Asia, Sub-Saharan Africa, which have lower average GDP per capita than the base region, and it is positive for Latin American \& the Caribbean and North America, with higher average GDP per capita.

Finally, given the differences observed between the two communities of food-producing countries, we explore if the estimated effects of specialization are also different for the countries in those communities. We split the sample according to the two communities detected in the ACSN and re-estimate the models using panel data fixed effects. ${ }^{8}$ Table 5 presents the estimation results.

\footnotetext{
${ }^{8}$ Due to the lack of space, we do not present the estimation results using all estimation methods. However, the results and conclusions hold with all estimation methods. Results are available upon request.
}

For countries in the more developed community, we estimate that concentrating production negatively affects all dependent variables. This effect is also negative but only statistically significant in the case of food supply for the sample of countries in the less developed community. Similarly, a coherent diversification pattern positively affects food supply, food security, and sustainability for the more developed community. In contrast, this positive effect is only statistically significant for food supply in the case of the less developed community. Finally, fitness has a significant and positive effect on food supply of both communities and not statistically significant on food security. Conversely, the effect of fitness is negative for the sustainability of the less developed community.

\section{Discussion}

Global food systems have faced unprecedented pressure, changes, and challenges in recent years. However, the agricultural product space and the agricultural countries space networks are 
Table 3

The effect of country specialization patterns on food security.

\begin{tabular}{|c|c|c|c|c|c|c|c|c|c|c|c|c|}
\hline \multirow{2}{*}{$\begin{array}{l}\text { Dependent variable } \\
\text { Model }\end{array}$} & \multicolumn{3}{|c|}{ POLS } & \multicolumn{3}{|c|}{ IV POLS } & \multicolumn{3}{|c|}{$\mathrm{FE}$} & \multicolumn{3}{|c|}{ IV FE } \\
\hline & (1) & (2) & (3) & (4) & (5) & (6) & (7) & (8) & (9) & (10) & (11) & (12) \\
\hline Entropy & $\begin{array}{l}0.025^{* * *} \\
(0.004)\end{array}$ & & & $\begin{array}{l}0.025^{* * *} \\
(0.004)\end{array}$ & & & $\begin{array}{c}0.013 \\
(0.010)\end{array}$ & & & $\begin{array}{c}0.013^{*} \\
(0.007)\end{array}$ & & \\
\hline Coherence & & $\begin{array}{l}0.064^{* * *} \\
(0.006)\end{array}$ & & & $\begin{array}{c}0.063^{* * *} \\
(0.006)\end{array}$ & & & $\begin{array}{c}0.019 \\
(0.015)\end{array}$ & & & $\begin{array}{c}0.024^{* * *} \\
(0.009)\end{array}$ & \\
\hline Fitness (ln) & & & $\begin{array}{l}0.022^{* * *} \\
(0.003)\end{array}$ & & & $\begin{array}{l}0.022^{* * *} \\
(0.003)\end{array}$ & & & $\begin{array}{c}0.006 \\
(0.006)\end{array}$ & & & $\begin{array}{c}0.006 \\
(0.005)\end{array}$ \\
\hline Agr. TFP (ln) & $\begin{array}{c}0.065^{* * *} \\
(0.014)\end{array}$ & $\begin{array}{c}0.065^{* * *} \\
(0.013)\end{array}$ & $\begin{array}{c}0.057^{* * *} \\
(0.013)\end{array}$ & $\begin{array}{c}0.044^{* * *} \\
(0.011)\end{array}$ & $\begin{array}{c}0.039^{* * *} \\
(0.011)\end{array}$ & $\begin{array}{c}0.033^{* * *} \\
(0.011)\end{array}$ & $\begin{array}{c}0.060^{* * * *} \\
(0.013)\end{array}$ & $\begin{array}{c}0.059^{* * * *} \\
(0.013)\end{array}$ & $\begin{array}{c}0.058^{* * * *} \\
(0.013)\end{array}$ & $\begin{array}{c}0.059^{* * * *} \\
(0.005)\end{array}$ & $\begin{array}{c}0.058^{* * * *} \\
(0.005)\end{array}$ & $\begin{array}{c}0.057^{* * *} \\
(0.005)\end{array}$ \\
\hline Human Capital & $\begin{array}{l}0.082^{* * *} \\
(0.004)\end{array}$ & $\begin{array}{l}0.083^{* * *} \\
(0.004)\end{array}$ & $\begin{array}{c}0.083^{* * *} \\
(0.004)\end{array}$ & $\begin{array}{l}0.079 * * * \\
(0.004)\end{array}$ & $\begin{array}{l}0.081^{* * *} \\
(0.004)\end{array}$ & $\begin{array}{l}0.081^{* * *} \\
(0.004)\end{array}$ & $\begin{array}{l}0.081^{* * *} \\
(0.013)\end{array}$ & $\begin{array}{l}0.082^{* * *} \\
(0.013)\end{array}$ & $\begin{array}{c}0.082^{* * *} \\
(0.013)\end{array}$ & $\begin{array}{l}0.084^{* * *} \\
(0.005)\end{array}$ & $\begin{array}{l}0.084^{* * *} \\
(0.005)\end{array}$ & $\begin{array}{l}0.085^{* * *} \\
(0.005)\end{array}$ \\
\hline Imports (ln) & $\begin{array}{l}0.043^{* * *} \\
(0.002)\end{array}$ & $\begin{array}{l}0.047^{* * *} \\
(0.002)\end{array}$ & $\begin{array}{l}0.050^{* * *} \\
(0.002)\end{array}$ & $\begin{array}{l}0.043^{* * * *} \\
(0.002)\end{array}$ & $\begin{array}{l}0.047^{* * *} \\
(0.002)\end{array}$ & $\begin{array}{l}0.050^{* * *} \\
(0.002)\end{array}$ & $\begin{array}{l}0.008^{* *} \\
(0.004)\end{array}$ & $\begin{array}{l}0.008^{* *} \\
(0.004)\end{array}$ & $\begin{array}{l}0.008^{* *} \\
(0.004)\end{array}$ & $\begin{array}{l}0.007^{* * *} \\
(0.002)\end{array}$ & $\begin{array}{l}0.007^{* * *} \\
(0.002)\end{array}$ & $\begin{array}{l}0.008^{* * *} \\
(0.002)\end{array}$ \\
\hline Latitude (Abs. Value) & $\begin{array}{c}0.000 \\
(0.000)\end{array}$ & $\begin{array}{c}0.000 \\
(0.000)\end{array}$ & $\begin{array}{c}0.000 \\
(0.000)\end{array}$ & $\begin{array}{c}0.000 \\
(0.000)\end{array}$ & $\begin{array}{c}0.000 \\
(0.000)\end{array}$ & $\begin{array}{c}0.000 \\
(0.000)\end{array}$ & & & & & & \\
\hline Community & $\begin{array}{l}0.042^{* * *} \\
(0.009)\end{array}$ & $\begin{array}{l}0.023^{* *} \\
(0.010)\end{array}$ & $\begin{array}{l}0.023^{* *} \\
(0.010)\end{array}$ & $\begin{array}{l}0.041^{* * *} \\
(0.009)\end{array}$ & $\begin{array}{l}0.022^{* *} \\
(0.010)\end{array}$ & $\begin{array}{l}0.022^{* *} \\
(0.011)\end{array}$ & & & & & & \\
\hline Europe \& Central Asia & $\begin{array}{c}0.034^{* * *} \\
(0.008)\end{array}$ & $\begin{array}{c}0.022^{* * *} \\
(0.008)\end{array}$ & $\begin{array}{c}0.037^{* * * *} \\
(0.008)\end{array}$ & $\begin{array}{c}0.035^{* * * *} \\
(0.008)\end{array}$ & $\begin{array}{c}0.023^{* * *} \\
(0.008)\end{array}$ & $\begin{array}{c}0.038^{* * *} \\
(0.008)\end{array}$ & & & & & & \\
\hline $\begin{array}{l}\text { Latin America \& } \\
\text { Caribbean }\end{array}$ & $\begin{array}{c}-0.025^{* * *} \\
(0.006)\end{array}$ & $\begin{array}{c}-0.023^{* * * *} \\
(0.006)\end{array}$ & $\begin{array}{c}-0.022^{* * *} \\
(0.005)\end{array}$ & $\begin{array}{c}-0.025^{* * *} \\
(0.006)\end{array}$ & $\begin{array}{c}-0.023^{* * * *} \\
(0.006)\end{array}$ & $\begin{array}{c}-0.022^{* * *} \\
(0.005)\end{array}$ & & & & & & \\
\hline $\begin{array}{l}\text { Middle East \& North } \\
\text { Africa }\end{array}$ & $\begin{array}{l}0.032^{* * *} \\
(0.008)\end{array}$ & $\begin{array}{l}0.023^{* * *} \\
(0.008)\end{array}$ & $\begin{array}{l}0.033^{* * *} \\
(0.008)\end{array}$ & $\begin{array}{l}0.030^{* * *} \\
(0.008)\end{array}$ & $\begin{array}{l}0.021^{* * *} \\
(0.008)\end{array}$ & $\begin{array}{l}0.031^{* * *} \\
(0.008)\end{array}$ & & & & & & \\
\hline North America & $\begin{array}{l}0.061^{* * *} \\
(0.009)\end{array}$ & $\begin{array}{l}0.043^{* * *} \\
(0.009)\end{array}$ & $\begin{array}{l}0.044^{* * *} \\
(0.009)\end{array}$ & $\begin{array}{l}0.062^{* * *} \\
(0.010)\end{array}$ & $\begin{array}{l}0.044^{* * *} \\
(0.009)\end{array}$ & $\begin{array}{l}0.046^{* * *} \\
(0.010)\end{array}$ & & & & & & \\
\hline South Asia & $\begin{array}{c}0.003 \\
(0.007)\end{array}$ & $\begin{array}{l}-0.004 \\
(0.007)\end{array}$ & $\begin{array}{l}-0.015^{*} \\
(0.008)\end{array}$ & $\begin{array}{c}0.001 \\
(0.007)\end{array}$ & $\begin{array}{l}-0.006 \\
(0.007)\end{array}$ & $\begin{array}{c}-0.017^{* *} \\
(0.008)\end{array}$ & & & & & & \\
\hline Sub-Saharan Africa & $\begin{array}{c}-0.066^{* * *} \\
(0.006)\end{array}$ & $\begin{array}{c}-0.055^{* * *} \\
(0.006)\end{array}$ & $\begin{array}{c}-0.052^{* * *} \\
(0.006)\end{array}$ & $\begin{array}{c}-0.068^{* * *} \\
(0.006)\end{array}$ & $\begin{array}{c}-0.057^{* * *} \\
(0.006)\end{array}$ & $\begin{array}{c}-0.054^{* * *} \\
(0.006)\end{array}$ & & & & & & \\
\hline Observations & 2,707 & 2,707 & 2,707 & 2,580 & 2,580 & 2,580 & 2,707 & 2,707 & 2,707 & 2,580 & 2,580 & 2,580 \\
\hline R-squared & 0.813 & 0.821 & 0.819 & 0.813 & 0.821 & 0.819 & 0.425 & 0.423 & 0.422 & 0.414 & 0.412 & 0.411 \\
\hline Number of countries & & & & & & & 129 & 129 & 129 & 129 & 129 & 129 \\
\hline Dependent variables & & & & & & First stage & & & & & & \\
\hline Entropy Index ${ }_{t-1}$ & & & & $\begin{array}{l}0.957^{* * * *} \\
(0.003)\end{array}$ & & & & & & $\begin{array}{l}0.556^{* * *} \\
(0.017)\end{array}$ & & \\
\hline Coherence $_{t-1}$ & & & & & $\begin{array}{l}0.063^{* * *} \\
(0.014)\end{array}$ & & & & & & $\begin{array}{l}0.681^{* * *} \\
(0.005)\end{array}$ & \\
\hline Fitness $_{t-1}(\ln )$ & & & & & & $\begin{array}{l}0.022^{* * *} \\
(0.002)\end{array}$ & & & & & & $\begin{array}{c}0.675^{* * *} \\
(0.014)\end{array}$ \\
\hline Partial F-test of IVs & & & & $27,449.57$ & $65,458.87$ & $90,550.83$ & & & & 1127.46 & 2210.37 & 2300.38 \\
\hline p-value & & & & 0.000 & 0.000 & 0.000 & & & & 0.000 & 0.000 & 0.000 \\
\hline Endogeneity test & & & & 1.483 & 0.080 & 2.061 & & & & 0.008 & 0.692 & 0.143 \\
\hline p-value & & & & 0.223 & 0.234 & 0.151 & & & & 0.929 & 0.405 & 0.705 \\
\hline
\end{tabular}

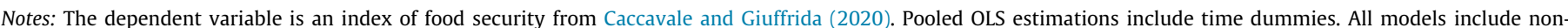

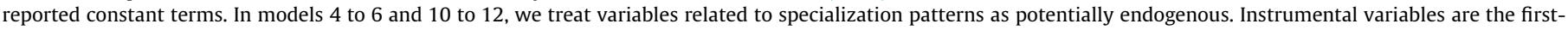

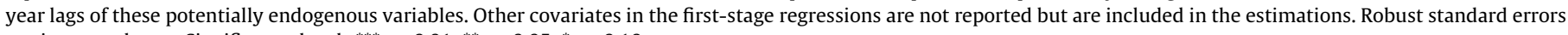
are in parentheses. Significance level: ${ }^{* * *} \mathrm{p}<0.01,{ }^{* *} \mathrm{p}<0.05,{ }^{*} \mathrm{p}<0.10$.

relatively stable over the period 1993-2013. This relative stability indicates that the possibilities of diversification into new products are strongly determined by the capabilities revealed in the products currently produced (Campi et al., 2020).

The first contribution of this study is to show that foodproducing countries can be empirically and consistently classified into two groups defined by their revealed capabilities or comparative advantages. The two groups have different features and performance, and significant differences in their specialization patterns, reflecting persistent gaps in production patterns at the global level.

Thus, despite globalization, increasing food trade, and changes in diets, there remain large and persistent differences in countries ability to feed themselves and protect the long-term productive capacity of their natural resources (Hazell \& Wood, 2007). Similarly, some authors have identified persistent differences in countries capabilities of engaging in food trade. For example, Torreggiani et al. (2018) show that the individual crop-specific layers of the multi-network have densely connected trading groups consistently over 2001-2011 but with substantial heterogeneity across layers in each year. The layers are mostly assortative, implying that more intensively connected countries tend to import from and export to countries that are themselves more connected.

These differences seem to be determined by environmental conditions, but also by technological, political, economic, and institutional factors (Choudhury \& Headey, 2017; Campi et al., 2020). Of course, biodiversity and environmental conditions affect food production and the possibilities of diversification. In fact, Nelson et al. (2016) show that gaps in the latitudinal production and consumption of plant diversity and richness have remained relatively static over time despite economic globalization, and countries plant production and consumption patterns are still largely determined by local evolutionary legacies of plant diversification. Because tropical countries harbor greater biodiversity than temperate countries, tropical countries produce and consume a greater diversity of plant products than do temperate countries. In contrast, richer and more economically advanced temperate countries have the capacity to 
Table 4

The effect of country specialization patterns on food systems sustainability.

\begin{tabular}{|c|c|c|c|c|c|c|c|c|c|c|c|c|}
\hline \multirow{2}{*}{$\begin{array}{l}\text { Dependent variable } \\
\text { Model }\end{array}$} & \multicolumn{3}{|c|}{ POLS } & \multicolumn{3}{|c|}{ IV POLS } & \multicolumn{3}{|c|}{$\mathrm{FE}$} & \multicolumn{3}{|c|}{ IV FE } \\
\hline & (1) & (2) & (3) & (4) & (5) & (6) & (7) & (8) & (9) & (10) & (11) & $(12)$ \\
\hline Entropy & $\begin{array}{c}0.007 \\
(0.007)\end{array}$ & & & $\begin{array}{c}0.014^{*} \\
(0.008)\end{array}$ & & & $\begin{array}{c}0.017^{*} \\
(0.010)\end{array}$ & & & $\begin{array}{c}0.130 \\
(0.108)\end{array}$ & & \\
\hline Coherence & & $\begin{array}{c}-0.035^{* * *} \\
(0.013)\end{array}$ & & & $\begin{array}{c}-0.035^{* *} \\
(0.015)\end{array}$ & & & $\begin{array}{c}0.015 \\
(0.012)\end{array}$ & & & $\begin{array}{c}0.192^{*} \\
(0.112)\end{array}$ & \\
\hline Fitness (ln) & & & $\begin{array}{l}-0.005 \\
(0.004)\end{array}$ & & & $\begin{array}{l}-0.005 \\
(0.004)\end{array}$ & & & $\begin{array}{c}-0.016^{* *} \\
(0.008)\end{array}$ & & & $\begin{array}{c}0.014 \\
(0.106)\end{array}$ \\
\hline Agr. TFP (ln) & $\begin{array}{l}-0.038 \\
(0.033)\end{array}$ & $\begin{array}{l}-0.034 \\
(0.031)\end{array}$ & $\begin{array}{l}-0.037 \\
(0.032)\end{array}$ & $\begin{array}{l}-0.035 \\
(0.027)\end{array}$ & $\begin{array}{l}-0.030 \\
(0.026)\end{array}$ & $\begin{array}{l}-0.033 \\
(0.026)\end{array}$ & $\begin{array}{l}0.057^{* * *} \\
(0.014)\end{array}$ & $\begin{array}{l}0.054^{* * *} \\
(0.013)\end{array}$ & $\begin{array}{l}0.053^{* * *} \\
(0.013)\end{array}$ & $\begin{array}{l}0.080^{* *} \\
(0.037)\end{array}$ & $\begin{array}{l}0.079 * * * \\
(0.026)\end{array}$ & $\begin{array}{l}0.045^{* * *} \\
(0.011)\end{array}$ \\
\hline Human Capital & $\begin{array}{l}0.075^{* * *} \\
(0.008)\end{array}$ & $\begin{array}{l}0.072^{* * *} \\
(0.008)\end{array}$ & $\begin{array}{l}0.075^{* * *} \\
(0.008)\end{array}$ & $\begin{array}{l}0.074^{* * *} \\
(0.009)\end{array}$ & $\begin{array}{l}0.071^{* * *} \\
(0.008)\end{array}$ & $\begin{array}{l}0.074^{* * *} \\
(0.009)\end{array}$ & $\begin{array}{l}0.039^{* * *} \\
(0.014)\end{array}$ & $\begin{array}{l}0.042^{* * *} \\
(0.013)\end{array}$ & $\begin{array}{l}0.043^{* * *} \\
(0.014)\end{array}$ & $\begin{array}{c}0.040 \\
(0.026)\end{array}$ & $\begin{array}{l}0.055^{* * *} \\
(0.020)\end{array}$ & $\begin{array}{c}0.058^{*} \\
(0.033)\end{array}$ \\
\hline Imports (ln) & $\begin{array}{l}0.029^{* * *} \\
(0.004)\end{array}$ & $\begin{array}{l}0.030^{* * *} \\
(0.003)\end{array}$ & $\begin{array}{l}0.029^{* * *} \\
(0.004)\end{array}$ & $\begin{array}{l}0.031^{* * *} \\
(0.004)\end{array}$ & $\begin{array}{l}0.032^{* * *} \\
(0.004)\end{array}$ & $\begin{array}{l}0.031^{* * *} \\
(0.004)\end{array}$ & $\begin{array}{c}0.006 \\
(0.004)\end{array}$ & $\begin{array}{c}0.007^{*} \\
(0.004)\end{array}$ & $\begin{array}{c}0.007^{*} \\
(0.004)\end{array}$ & $\begin{array}{c}0.002 \\
(0.010)\end{array}$ & $\begin{array}{c}0.008 \\
(0.006)\end{array}$ & $\begin{array}{l}0.010^{*} \\
(0.005)\end{array}$ \\
\hline Latitude (Abs. Value) & $\begin{array}{l}-0.000 \\
(0.000)\end{array}$ & $\begin{array}{l}-0.001 \\
(0.000)\end{array}$ & $\begin{array}{l}-0.000 \\
(0.000)\end{array}$ & $\begin{array}{l}-0.000 \\
(0.000)\end{array}$ & $\begin{array}{l}-0.000 \\
(0.000)\end{array}$ & $\begin{array}{l}-0.000 \\
(0.000)\end{array}$ & & & & & & \\
\hline Community & $\begin{array}{l}0.037^{* *} \\
(0.015)\end{array}$ & $\begin{array}{l}0.056^{* * *} \\
(0.016)\end{array}$ & $\begin{array}{l}0.044^{* * *} \\
(0.016)\end{array}$ & $\begin{array}{l}0.032^{* *} \\
(0.016)\end{array}$ & $\begin{array}{l}0.052^{* * *} \\
(0.018)\end{array}$ & $\begin{array}{l}0.041^{* *} \\
(0.017)\end{array}$ & & & & & & \\
\hline Europe \& Central Asia & $\begin{array}{l}-0.006 \\
(0.016)\end{array}$ & $\begin{array}{c}0.011 \\
(0.017)\end{array}$ & $\begin{array}{r}-0.000 \\
(0.016)\end{array}$ & $\begin{array}{r}-0.014 \\
(0.018)\end{array}$ & $\begin{array}{c}0.006 \\
(0.019)\end{array}$ & $\begin{array}{l}-0.005 \\
(0.018)\end{array}$ & & & & & & \\
\hline $\begin{array}{l}\text { Latin America \& } \\
\text { Caribbean }\end{array}$ & $\begin{array}{l}0.015^{*} \\
(0.009)\end{array}$ & $\begin{array}{l}0.027^{* * *} \\
(0.008)\end{array}$ & $\begin{array}{l}0.023^{* * *} \\
(0.008)\end{array}$ & $\begin{array}{c}0.011 \\
(0.010)\end{array}$ & $\begin{array}{l}0.027^{* * *} \\
(0.009)\end{array}$ & $\begin{array}{l}0.023^{* *} \\
(0.009)\end{array}$ & & & & & & \\
\hline $\begin{array}{l}\text { Middle East \& North } \\
\text { Africa }\end{array}$ & $\begin{array}{c}-0.210^{* * * *} \\
(0.023)\end{array}$ & $\begin{array}{c}-0.204^{* * *} \\
(0.022)\end{array}$ & $\begin{array}{c}-0.207^{* * *} \\
(0.023)\end{array}$ & $\begin{array}{c}-0.209^{* * * *} \\
(0.024)\end{array}$ & $\begin{array}{c}-0.202^{* * *} \\
(0.023)\end{array}$ & $\begin{array}{c}-0.205^{* * *} \\
(0.024)\end{array}$ & & & & & & \\
\hline North America & $\begin{array}{l}0.077^{* * *} \\
(0.013)\end{array}$ & $\begin{array}{l}0.088^{* * *} \\
(0.013)\end{array}$ & $\begin{array}{l}0.081^{* * *} \\
(0.014)\end{array}$ & $\begin{array}{l}0.076^{* * *} \\
(0.015)\end{array}$ & $\begin{array}{l}0.086^{* * *} \\
(0.015)\end{array}$ & $\begin{array}{l}0.080^{* * *} \\
(0.015)\end{array}$ & & & & & & \\
\hline South Asia & $\begin{array}{c}-0.122^{* * * *} \\
(0.013)\end{array}$ & $\begin{array}{l}-0.115^{* * *} \\
(0.015)\end{array}$ & $\begin{array}{c}-0.116^{* * *} \\
(0.015)\end{array}$ & $\begin{array}{c}-0.126^{* * *} \\
(0.013)\end{array}$ & $\begin{array}{c}-0.118^{* * *} \\
(0.015)\end{array}$ & $\begin{array}{c}-0.119 * * * \\
(0.016)\end{array}$ & & & & & & \\
\hline Sub-Saharan Africa & $\begin{array}{c}-0.023^{* *} \\
(0.009)\end{array}$ & $\begin{array}{l}-0.018^{* *} \\
(0.008)\end{array}$ & $\begin{array}{l}-0.018^{* *} \\
(0.008)\end{array}$ & $\begin{array}{c}-0.026^{* * *} \\
(0.010)\end{array}$ & $\begin{array}{l}-0.018^{* *} \\
(0.009)\end{array}$ & $\begin{array}{c}-0.018^{* *} \\
(0.009)\end{array}$ & & & & & & \\
\hline Observations & 448 & 448 & 448 & 362 & 362 & 362 & 448 & 448 & 448 & 362 & 362 & 362 \\
\hline R-squared & 0.801 & 0.805 & 0.801 & 0.802 & 0.807 & 0.803 & 0.310 & 0.301 & 0.312 & -0.302 & 0.060 & 0.249 \\
\hline Number of countries & & & & & & & 92 & 92 & 92 & 92 & 92 & 92 \\
\hline Dependent variables & & & & & & First stage & & & & & & \\
\hline Entropy Index ${ }_{t-1}$ & & & & $\begin{array}{l}0.932^{* * *} \\
(0.018)\end{array}$ & & & & & & $\begin{array}{l}0.171^{* * *} \\
(0.064)\end{array}$ & & \\
\hline Coherence $_{t-1}$ & & & & & $\begin{array}{c}0.957^{* * * *} \\
(0.014)\end{array}$ & & & & & & $\begin{array}{c}0.180^{* * *} \\
(0.054)\end{array}$ & \\
\hline Fitness $_{t-1}(\ln )$ & & & & & & $\begin{array}{l}0.966^{* * *} \\
(0.013)\end{array}$ & & & & & & $\begin{array}{l}-0.057 \\
(0.069)\end{array}$ \\
\hline Partial F-test of IVs & & & & 2651.22 & 4827.85 & 5758.39 & & & & 7.17 & 11.19 & 0.68 \\
\hline p-value & & & & 0.006 & 0.007 & 0.008 & & & & 0.008 & 0.010 & 0.41 \\
\hline Endogeneity test & & & & 6.739 & 0.080 & 0.176 & & & & 6.332 & 3.923 & 0.077 \\
\hline p-value & & & & 0.009 & 0.777 & 0.675 & & & & 0.012 & 0.048 & 0.789 \\
\hline
\end{tabular}

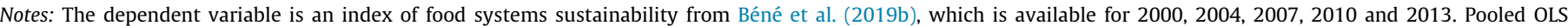

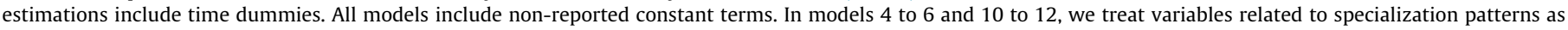

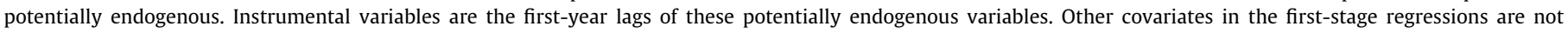
reported but are included in the estimations. Robust standard errors are in parentheses. Significance level: ${ }^{* * *} \mathrm{p}<0.01,{ }^{* *} \mathrm{p}<0.05,{ }^{*} \mathrm{p}<0.10$.

produce and consume more plant species than the generally poorer tropical countries, yet this collection of plant species is drawn from fewer branches on the tree of life.

Similarly, our analysis indicates striking differences in how two clearly differentiated groups of more and less developed countries use their capabilities for food production. Generalizing, these two communities of countries could also be seen as temperate versus tropical. The more developed or temperate community produces higher shares of food, and imports and exports more food per capita than the tropical or less developed community, although the shares of the population are similar in both communities.

This evidence indicates a persistent gap in production specialization, which needs to be addressed when seeking to reach the second SDG (zero hunger) because what countries produce and consume have implications on their food security, health, and sustainability (Tilman \& Clark, 2014).
Therefore, from the above derives the second contribution of the paper, which is related to understanding the effect of specialization patterns on food supply, food security, and sustainability. Different authors have recently shown that agricultural production has diversified but has also become more similar in composition (Khoury et al., 2014; Nelson et al., 2016; Aizen et al., 2019; Martin et al., 2019; Aguiar et al., 2020). Our study focuses on how countries use their capabilities to increase and diversify their national food supplies, considering the revealed heterogeneity of countries specialization patterns, and how this affects their food security and sustainability.

In agreement with the studies that analyze the world product space (for example, Hidalgo \& Hausmann, 2009; Zaccaria et al., 2014), the agricultural production space reveals that specialization patterns and their diversification depend on the income levels of countries. More competitive countries in food production have higher GDP, agricultural GPV, and export more food. Therefore, 
Table 5

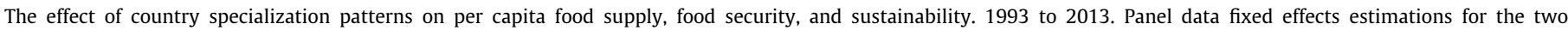
communities detected in the ACSN.

\begin{tabular}{|c|c|c|c|c|c|c|c|c|c|}
\hline \multirow{2}{*}{$\begin{array}{l}\text { Dependent variable } \\
\text { Model }\end{array}$} & \multicolumn{3}{|c|}{ Food Supply } & \multicolumn{3}{|c|}{ Food Security } & \multicolumn{3}{|c|}{ Sustainability } \\
\hline & (1) & $(2)$ & (3) & (4) & (5) & (6) & (7) & (8) & (9) \\
\hline & \multicolumn{9}{|c|}{ More Developed Community (blue) } \\
\hline Entropy Index & $\begin{array}{l}0.100^{* *} \\
(0.048)\end{array}$ & & & $\begin{array}{l}0.020^{* *} \\
(0.009)\end{array}$ & & & $\begin{array}{l}0.019 * * \\
(0.009)\end{array}$ & & \\
\hline Coherence & & $\begin{array}{c}0.256^{* * *} \\
(0.066)\end{array}$ & & & $\begin{array}{l}0.034^{* *} \\
(0.015)\end{array}$ & & & $\begin{array}{c}0.021^{*} \\
(0.011)\end{array}$ & \\
\hline Fitness (ln) & & & $\begin{array}{c}0.092^{*} \\
(0.051)\end{array}$ & & & $\begin{array}{l}-0.002 \\
(0.009)\end{array}$ & & & $\begin{array}{l}-0.010 \\
(0.008)\end{array}$ \\
\hline Agr. TFP (ln) & $\begin{array}{l}0.308^{* * *} \\
(0.079)\end{array}$ & $\begin{array}{c}0.306^{* * * *} \\
(0.078)\end{array}$ & $\begin{array}{c}0.317^{* * *} \\
(0.079)\end{array}$ & $\begin{array}{l}0.053^{* * *} \\
(0.015)\end{array}$ & $\begin{array}{c}0.053^{* * *} \\
(0.015)\end{array}$ & $\begin{array}{l}0.054^{* * *} \\
(0.016)\end{array}$ & $\begin{array}{l}0.058^{* *} \\
(0.024)\end{array}$ & $\begin{array}{l}0.054^{* *} \\
(0.022)\end{array}$ & $\begin{array}{l}0.055^{* *} \\
(0.024)\end{array}$ \\
\hline Human Capital & $\begin{array}{c}0.144^{*} \\
(0.082)\end{array}$ & $\begin{array}{c}0.118 \\
(0.077)\end{array}$ & $\begin{array}{l}0.155^{* *} \\
(0.077)\end{array}$ & $\begin{array}{c}0.056^{* * *} \\
(0.017)\end{array}$ & $\begin{array}{l}0.053^{* * *} \\
(0.018)\end{array}$ & $\begin{array}{l}0.056^{* * *} \\
(0.018)\end{array}$ & $\begin{array}{l}0.058^{* *} \\
(0.025)\end{array}$ & $\begin{array}{c}0.065^{* * *} \\
(0.024)\end{array}$ & $\begin{array}{l}0.061^{* *} \\
(0.025)\end{array}$ \\
\hline Imports (ln) & $\begin{array}{c}0.091^{* * *} \\
(0.022)\end{array}$ & $\begin{array}{c}0.092^{* * *} \\
(0.021)\end{array}$ & $\begin{array}{c}0.095^{* * * *} \\
(0.023)\end{array}$ & $\begin{array}{c}0.015^{* * *} \\
(0.005)\end{array}$ & $\begin{array}{c}0.016^{* * *} \\
(0.005)\end{array}$ & $\begin{array}{c}0.016^{* * *} \\
(0.005)\end{array}$ & $\begin{array}{c}0.005 \\
(0.006)\end{array}$ & $\begin{array}{c}0.006 \\
(0.006)\end{array}$ & $\begin{array}{c}0.007 \\
(0.006)\end{array}$ \\
\hline Observations & 1,300 & 1,300 & 1,300 & 1,300 & 1,300 & 1,300 & 207 & 207 & 207 \\
\hline R-squared & 0.427 & 0.442 & 0.427 & 0.499 & 0.498 & 0.485 & 0.440 & 0.425 & 0.424 \\
\hline \multirow[t]{2}{*}{ Countries } & 62 & 62 & 62 & 62 & 62 & 62 & 43 & 43 & 43 \\
\hline & \multicolumn{9}{|c|}{ Less Developed Community (red) } \\
\hline Entropy Index & $\begin{array}{l}0.133^{* *} \\
(0.061)\end{array}$ & & & $\begin{array}{c}0.003 \\
(0.022)\end{array}$ & & & $\begin{array}{c}0.009 \\
(0.023)\end{array}$ & & \\
\hline Coherence & & $\begin{array}{c}0.230^{*} \\
(0.117)\end{array}$ & & & $\begin{array}{c}0.003 \\
(0.033)\end{array}$ & & & $\begin{array}{c}0.010 \\
(0.028)\end{array}$ & \\
\hline Fitness (ln) & & & $\begin{array}{c}0.068^{*} \\
(0.036)\end{array}$ & & & $\begin{array}{c}0.010 \\
(0.010)\end{array}$ & & & $\begin{array}{l}-0.018^{*} \\
(0.011)\end{array}$ \\
\hline Agr. TFP (ln) & $\begin{array}{c}0.405^{* * *} \\
(0.086)\end{array}$ & $\begin{array}{c}0.394^{* * *} \\
(0.089)\end{array}$ & $\begin{array}{c}0.380^{* * * *} \\
(0.088)\end{array}$ & $\begin{array}{c}0.065^{* * *} \\
(0.021)\end{array}$ & $\begin{array}{c}0.065^{* * *} \\
(0.021)\end{array}$ & $\begin{array}{l}0.066^{* * *} \\
(0.021)\end{array}$ & $\begin{array}{l}0.053^{* * *} \\
(0.013)\end{array}$ & $\begin{array}{c}0.052^{* * *} \\
(0.013)\end{array}$ & $\begin{array}{l}0.050^{* * * *} \\
(0.013)\end{array}$ \\
\hline Human Capital & $\begin{array}{l}0.254^{* * *} \\
(0.071)\end{array}$ & $\begin{array}{c}0.277^{* * *} \\
(0.073)\end{array}$ & $\begin{array}{c}0.262^{* * *} \\
(0.073)\end{array}$ & $\begin{array}{l}0.105^{* * *} \\
(0.020)\end{array}$ & $\begin{array}{c}0.106^{* * *} \\
(0.019)\end{array}$ & $\begin{array}{c}0.103^{* * *} \\
(0.019)\end{array}$ & $\begin{array}{c}0.028^{*} \\
(0.016)\end{array}$ & $\begin{array}{c}0.028^{*} \\
(0.016)\end{array}$ & $\begin{array}{l}0.033^{* *} \\
(0.015)\end{array}$ \\
\hline Imports (ln) & $\begin{array}{c}0.112^{* * *} \\
(0.021)\end{array}$ & $\begin{array}{c}0.109 * * * \\
(0.020)\end{array}$ & $\begin{array}{c}0.114^{* * *} \\
(0.020)\end{array}$ & $\begin{array}{c}0.003 \\
(0.005)\end{array}$ & $\begin{array}{c}0.003 \\
(0.005)\end{array}$ & $\begin{array}{c}0.002 \\
(0.005)\end{array}$ & $\begin{array}{c}0.006 \\
(0.005)\end{array}$ & $\begin{array}{c}0.007 \\
(0.005)\end{array}$ & $\begin{array}{c}0.007 \\
(0.005)\end{array}$ \\
\hline Observations & 1,428 & 1,428 & 1,428 & 1,407 & 1,407 & 1,407 & 241 & 241 & 241 \\
\hline R-squared & 0.578 & 0.574 & 0.572 & 0.404 & 0.404 & 0.406 & 0.221 & 0.220 & 0.236 \\
\hline Countries & 68 & 68 & 68 & 67 & 67 & 67 & 49 & 49 & 49 \\
\hline
\end{tabular}

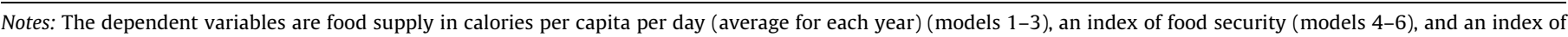

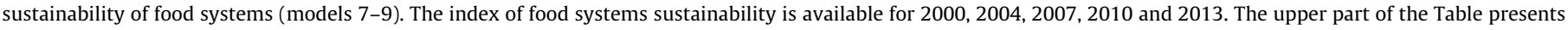

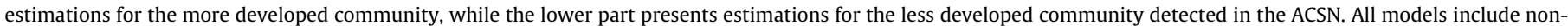
reported constant terms. Robust standard errors are in parentheses. Significance level: ${ }^{* * *} \mathrm{p}<0.01,{ }^{* *} \mathrm{p}<0.05,{ }^{*} \mathrm{p}<0.10$.

countries revealed capabilities, which include environmental conditions, technology, capital, institutions, and skills, are unevenly distributed between countries, and they shape national food production patterns and the global food system.

However, countries are able to produce a wide variety of food products, not only those for which they have revealed comparative advantages, which indicates that different factors play a role in determining their specialization. In addition to capabilities, other factors such as subsidies (Nelson et al., 2016), the governance of food production and trade (Oosterveer, 2007), intellectual property rights (Campi \& Nuvolari, 2020), or cultural factors, such as cultural preferences for diverse local food production (Vermeulen et al., 2020) can also affect production decisions.

Moreover, it is important to mention that the agricultural of food products included in FAO database and used in the study may underestimate the number of products and the diversity of production in several countries because some crops are primarily traded in local markets, home gardens or informally, or produced for subsistence consumption in isolated areas, or consumed in relatively small quantities (Khoury et al., 2014; Aguiar et al., 2020).

Therefore, the diversification of food production could be higher than revealed by recent studies that rely on FAO data. Indeed, diversification is a relevant and diffused characteristic of national food production baskets, and this feature could affect food supply and food security. Moreover, specialization and concentration could imply different resilience to face climatic shocks. For exam- ple, Nelson et al. (2016) argue that less specialized production patterns will make crop systems more resilient to zonal climatic and social perturbations, but this may come at the expense of global crop production efficiency, an important step in making the transition to a hotter and more crowded world. In addition, diverse food production can protect rural households in developing countries from food price shocks. In contrast, concentrating production in a few crops could make countries more vulnerable to production or climatic shocks endangering their food security (Campi et al., 2020).

Therefore, how different features of production patterns affect food supply, food security, and sustainability? Our analysis indicates that countries should promote a coherent diversification of agricultural production, exploiting and building new capabilities around existing ones, rather than specializing in a reduced number of products. This type of trajectory could increase the available food supply and contribute to reducing the risk of facing a food deficit. Moreover, to improve the overall sustainability of food systems, countries should reduce concentration. However, it might also be necessary to follow a different diversification pattern, generating changes in production systems, particularly for countries in the less developed community.

Although there is space for improvements in all cases, countries with better food security and sustainability are mainly in the more developed community. In general, countries in the less developed community lag behind in terms of food security, sustainability, or both. At the global level, the gap that divides food-producing 
countries needs to be addressed to achieve food security and a more sustainable global food system.

In brief, the evidence indicates that there might be certain production patterns improving food security and reducing the risk of facing a food deficit (SDGs: Targets 2.1 and 2.2) and simultaneously increasing the sustainability of food systems (SDGs: Target 2.4). This is a piece of interesting evidence because food security and the environmental dimension of sustainable development are linked by bidirectional interconnections that can lead to a tradeoff between increasing food supply and improving food systems sustainability. Increasing competitiveness, production, or productivity can undoubtedly have an impact on the environment. However, at least in the long-run, producing more and better food requires a healthy environment.

This evidence can contribute to policies seeking to achieve global food security and more sustainable development of agriculture by providing inputs to understand specialization patterns of agricultural production and its dynamics. At the country level, an improvement in both food security and sustainability implies understanding idiosyncratic factors, such as culture, society, and the environment, that define their production and diversification patterns. Capabilities, in a broad sense, might reflect these factors shaping production baskets and the possibilities of change according to the needs of the population. From a policy perspective, the agricultural product space network can indicate countries the path needed to upgrade or diversify their agricultural production baskets, react to changes in food demand, or climate change, and improve their food systems.

To advance this work and for more comprehensive policy advises, not only production but also food trade and food waste, which altogether determine food supply, need to be considered. Transforming food demand through changes in diets is becoming increasingly relevant to achieve food security and a more sustainable food system (Vermeulen et al., 2020). Besides, food trade has been increasing and shaping food supplies worldwide, given that local food crop production could fulfill demand for less than onethird of the population, as Kinnunen et al. (2020) discuss. Given that the position of countries in food trade dynamics also affects their decisions in food production specialization, our analysis opens the ground for trade policy considerations (SDGs: Target 2. b).

Finally, our analysis focuses on the average features of countries to characterize food systems. However, there exist vast differences within countries that should be considered when seeking to reach SDGs. Similarly, comparative advantages within a country can be heterogeneous, and opportunities for adjustment within countries are important (Donaldson, 2019).

\section{Conclusions}

In this paper, we study the bipartite networks of agricultural products and food-producing countries, which allows us to build the product-product and country-country relatedness networks. Both networks are well characterized by a modular structure. In the agricultural product space networks, products group in four communities that need similar production capabilities. In the network of food-producing countries, countries cluster in two stable and distinct communities, characterized by relatively similar endowments of capabilities for agricultural production. One community mainly includes high- and middle-income countries with relatively developed agricultural systems, while the other mostly groups low- and middle-income countries with less developed agricultural systems. The former community produces higher shares of food, and imports and exports more food per capita, although the shares of the population are similar in both communities. This evidence indicates a persistent gap in production specialization, which needs to be addressed to achieve food security and more sustainable food systems.

We show that the measure of competitiveness, which considers the quality and variety of countries food production baskets, is positively correlated with different macro indicators, such as agricultural gross production value, gross domestic product, and agricultural exports. Moreover, competitiveness is positively associated with food supply, multidimensional indicators of food security, and food systems sustainability. In general, most competitive countries belong to the more developed community. Our findings agree with the studies that show that specialization patterns and the mix of goods that a country produces have important implications for economic growth (for example, Hausmann et al., 2007; Hidalgo et al., 2007).

We show that concentrating production decreases food supply, food security, and sustainability levels of countries. We find that competitiveness is positively related to food supply and food security. This evidence indicates that promoting diversification of agricultural production, rather than specialization, reduces the risk of facing a food deficit. We estimate an additional gain when diversification is coherent, which implies that countries benefit by exploiting their existing capabilities. Instead, we find that more competitive agricultural systems that follow a coherent diversification pattern, particularly for countries in the less developed community, might harm food systems sustainability. These results reflect the trade-off between achieving food security while simultaneously improving sustainability.

This evidence can help improve our understanding of agricultural production, which is crucial to achieve food security and sustainable food systems and to address the trade-offs that might emerge in pursuing both. Therefore, we conclude that understanding food systems from an evolving complex network perspective can provide relevant elements to reach the SDGs.

\section{Declaration of Competing Interest}

The authors declare that they have no known competing financial interests or personal relationships that could have appeared to influence the work reported in this paper.

\section{Acknowledgement}

The authors would like to thank Elena Vallino and Donatella Saccone for their support, suggestions, and helpful feedback. We also thank participants at the 2019 ICABR Conference (Ravello, Italy), Sustainability and Development Conference 2019, Michigan University (Ann Arbor, United States), and at a seminar at CIAT (Palmira, Colombia, 2019) for useful comments and suggestions on earlier drafts of this paper.

\section{Appendix A}

Fig. A.1, Tables A.1, A.2, A.3, A.4. 

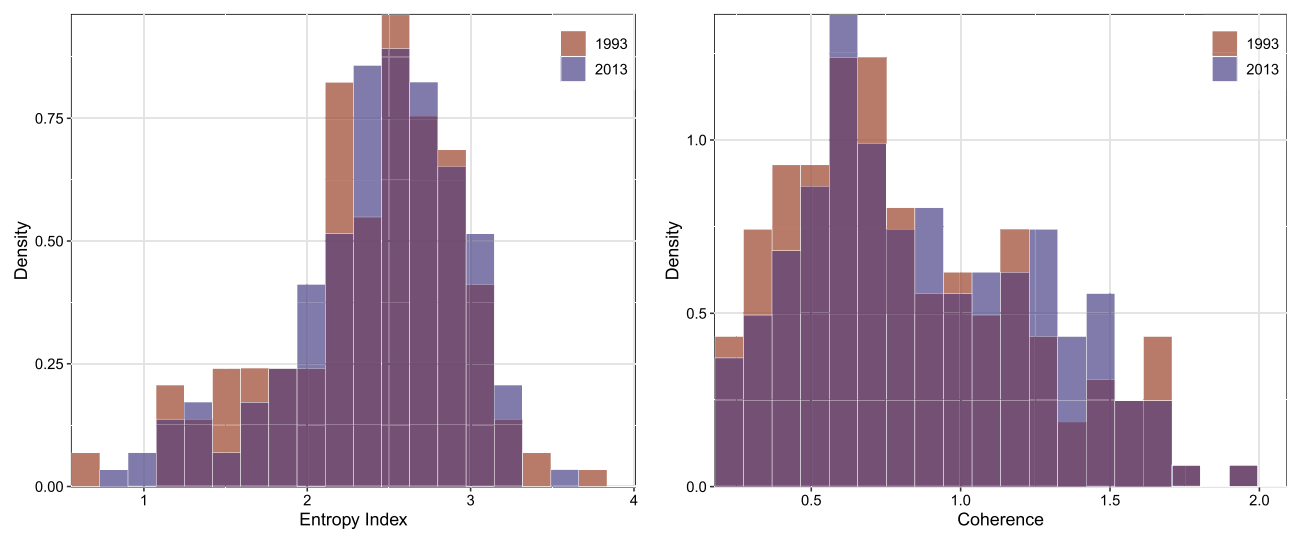

Fig. A.1. Distributions of the Entropy index (left) and the indicator of Coherence (right). 1993 and 2013.

Table A.1

List of countries, ISO codes, geographical regions, income levels, and communities.

\begin{tabular}{|c|c|c|c|c|c|c|c|c|}
\hline Country & ISO & Reg. & Country & ISO & Reg. & Country & ISO & Reg. \\
\hline \multicolumn{9}{|c|}{ More Developed Community (Blue) } \\
\hline Afghanistan & AFG & SAS & Germany* & DEU & ECA & Poland* & POL & ECA \\
\hline Albania** & ALB & ECA & Greece* $^{*}$ & GRC & ECA & Portugal* & PRT & ECA \\
\hline Algeria** & DZA & MNA & Hungary* & HUN & ECA & Rep. of Korea* & KOR & EAP \\
\hline Antigua and Barbuda** & ATG & LAC & Iceland* & ISL & ECA & Rep. of Moldova** & MDA & ECA \\
\hline Argentina** & ARG & LAC & $\operatorname{Iran}^{* *}$ & IRN & MNA & Romania** & ROU & ECA \\
\hline Armenia** & ARM & ECA & Iraq $^{* *}$ & IRQ & MNA & Russian Federation** & RUS & ECA \\
\hline Australia* & AUS & EAP & Ireland* & IRL & ECA & Saudi Arabia* & SAU & MNA \\
\hline Austria* & AUT & ECA & Israel* & ISR & MNA & Slovakia* & SVK & ECA \\
\hline Azerbaijan** & AZE & ECA & Italy* & ITA & ECA & Slovenia* & SVN & ECA \\
\hline Belarus** & BLR & ECA & Japan* & JPN & EAP & South Africa** & ZAF & SSA \\
\hline Bermuda* & BMU & NAM & Jordan** & JOR & MNA & Spain* & ESP & ECA \\
\hline Bosnia and Herzegovina** & $\mathrm{BIH}$ & ECA & Kazakhstan** & $\mathrm{KAZ}$ & ECA & Sweden* & SWE & ECA \\
\hline Bulgaria** & BGR & ECA & Korea, DPR & PRK & EAP & Switzerland* & CHE & ECA \\
\hline Canada* & CAN & NAM & Kuwait* & KWT & MNA & Tajikistan & TJK & ECA \\
\hline Chile** & $\mathrm{CHL}$ & LAC & Kyrgyzstan & KGZ & ECA & North Macedonia** & MKD & ECA \\
\hline China** & $\mathrm{CHN}$ & EAP & Latvia** & LVA & ECA & Tunisia** & TUN & MNA \\
\hline Croatia* & HRV & ECA & Lebanon** & LBN & MNA & Turkey** & TUR & ECA \\
\hline Cyprus* & CYP & ECA & Lithuania** & LTU & ECA & Turkmenistan** & TKM & ECA \\
\hline Czech Rep.* & CZE & ECA & Malta* & MLT & MNA & Ukraine ${ }^{* *}$ & UKR & ECA \\
\hline Denmark* & DNK & ECA & Mongolia** & MNG & EAP & United Arab Emirates* & ARE & MNA \\
\hline Egypt** & EGY & MNA & Morocco $^{* *}$ & MAR & MNA & United Kingdom* & GBR & ECA \\
\hline Estonia* & EST & ECA & Netherlands* & NLD & ECA & United States of America* & USA & NAM \\
\hline Finland* & FIN & ECA & New Zealand* & NZL & EAP & Uruguay** & URY & LAC \\
\hline France* & FRA & ECA & Norway* & NOR & ECA & Uzbekistan** & UZB & ECA \\
\hline Feorgia** & GEO & ECA & Oman* & OMN & MNA & Yemen** & YEM & MNA \\
\hline \multicolumn{9}{|c|}{ Less Developed Community (Red) } \\
\hline Angola** & AGO & SSA & Gambia & GMB & SSA & Nigeria** & NGA & SSA \\
\hline Bahamas* & BHS & LAC & Ghana** & GHA & SSA & Pakistan** & PAK & SAS \\
\hline Bangladesh & BGD & SAS & Grenada** & GRD & LAC & Panama** & PAN & LAC \\
\hline Barbados* & BRB & LAC & Guatemala** & GTM & LAC & Paraguay** & PRY & LAC \\
\hline Belize** & BLZ & LAC & Guinea & GIN & SSA & Peru** & PER & LAC \\
\hline Benin & BEN & SSA & Guinea-Bissau & GNB & SSA & Philippines** & PHL & EAP \\
\hline Bolivia** & BOL & LAC & Guyana** & GUY & LAC & Rwanda & RWA & SSA \\
\hline Botswana** & BWA & SSA & Haiti & HTI & LAC & Saint Kitts and Nevis** & KNA & LAC \\
\hline Brazil $^{* *}$ & BRA & LAC & Honduras** & HND & LAC & Saint Lucia** & LCA & LAC \\
\hline Brunei Darussalam* & BRN & EAP & India** & IND & SAS & Samoa** & WSM & EAP \\
\hline Burkina Faso & BFA & SSA & Indonesia** & IDN & EAP & Sao Tome and Principe ${ }^{* *}$ & STP & SSA \\
\hline Cambodia & KHM & EAP & Jamaica** & JAM & LAC & Senegal ${ }^{* *}$ & SEN & SSA \\
\hline Cameroon** & CMR & SSA & Kenya & KEN & SSA & Sierra Leone & SLE & SSA \\
\hline Cape Verde ${ }^{* *}$ & CPV & SSA & Kiribati** & KIR & EAP & Solomon Islands** & SLB & EAP \\
\hline Central African Rep. & CAF & SSA & Lao PDR ${ }^{* *}$ & LAO & EAP & Sri Lanka** & LKA & SAS \\
\hline Chad & TCD & SSA & Lesotho** & LSO & SSA & St. Vincent \& Grenadines** & VCT & LAC \\
\hline China, Hong Kong SAR* & HKG & EAP & Liberia & LBR & SSA & Suriname ${ }^{* *}$ & SUR & LAC \\
\hline China, Macao SAR* & MAC & EAP & Madagascar & MDG & SSA & Swaziland** & SWZ & SSA \\
\hline Colombia** & $\mathrm{COL}$ & LAC & Malawi & MWI & SSA & Taiwan (China)* & TWN & EAP \\
\hline Congo, Rep.** & COG & SSA & Malaysia** & MYS & EAP & Thailand** & THA & EAP \\
\hline Costa Rica** & CRI & LAC & Maldives** & MDV & SAS & Timor-Leste ${ }^{* *}$ & TLS & EAP \\
\hline Céte d'Ivoire** & CIV & SSA & Mali & MLI & SSA & Togo & TGO & SSA \\
\hline Cuba** & CUB & LAC & Mauritania** & MRT & SSA & Trinidad and Tobago* & TTO & LAC \\
\hline Djibouti** & DJI & MNA & Mauritius** & MUS & SSA & Uganda & UGA & SSA \\
\hline
\end{tabular}


Table A.1 (continued)

\begin{tabular}{|c|c|c|c|c|c|c|c|c|}
\hline Country & ISO & Reg. & Country & ISO & Reg. & Country & ISO & Reg. \\
\hline Dominica** & DMA & LAC & Mexico** $^{* *}$ & MEX & LAC & United Rep. of Tanzania & TZA & SSA \\
\hline Dominican Rep.** & DOM & LAC & Mozambique & $\mathrm{MOZ}$ & SSA & Vanuatu** & VUT & EAP \\
\hline Ecuador** & ECU & LAC & Myanmar & MMR & EAP & Venezuela** & VEN & LAC \\
\hline El Salvador** & SLV & LAC & Namibia** & NAM & SSA & Viet Nam** & VNM & EAP \\
\hline Ethiopia & ETH & SSA & Nepal & NPL & SAS & Zambia** & ZMB & SSA \\
\hline Fiji** & FJI & EAP & New Caledonia* & NCL & EAP & Zimbabwe & ZWE & SSA \\
\hline French Polynesia* & PYF & EAP & Nicaragua** & NIC & LAC & & & \\
\hline Gabon** & GAB & SSA & Niger & NER & SSA & & & \\
\hline
\end{tabular}

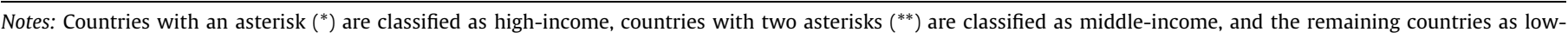

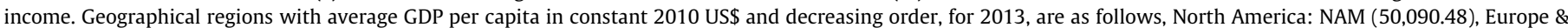

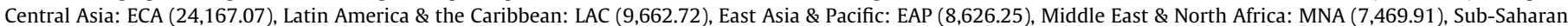
Africa: SSA (1,659.56), South Asia: SAS $(1,421.68)$. Income levels and geographical regions are from World Bank (2019).

Table A.2

List of agricultural products.

Crops

Almonds, with shell; Anise, badian, fennel, coriander; Apples; Apricots; Artichokes; Asparagus; Avocados; Bambara beans; Bananas; Barley; Broad beans, horse beans, dry; Beans, dry; Beans, green; Berries nes; Blueberries; Brazil nuts, with shell; Buckwheat; Cabbages and other brassicas; Canary seed; Carobs; Carrots and turnips; Cashewapple; Cashew nuts, with shell; Cassava; Cassava leaves; Cauliflowers and broccoli; Cereals, nes; Cherries; Cherries, sour; Chestnut; Chick peas; Chicory roots; Chillies and peppers, green; Chillies and peppers, dry; Cinnamon (canella); Fruit, citrus nes; Cloves; Cocoa, beans; Coconuts; Coffee, green; Cottonseed; Cow peas, dry; Cranberries; Cucumbers and gherkins; Currants Dates; Eggplants (aubergines); Figs; Fonio; Fruit, fresh nes; Fruit, pome nes; Fruit, stone nes; Garlic; Ginger; Gooseberries; Grain, mixed; Grapefruit (Inc. pomelos); Grapes; Groundnuts, with shell; Hazelnuts, with shell; Hempseed; Hops; Karite nuts (sheanuts); Kiwi fruit; Leeks, other alliaceous vegetables; Lemons and limes; Lentils; Lettuce and chicory; Linseed; Lupins; Maize; Maize, green; Mangoes, mangosteens, guavas; Mate; Melons, other (Inc.cantaloupes); Melonseed; Millet; Mushrooms and truffles; Mustard seed; Nutmeg, mace and cardamoms; Areca nuts; Kola nuts; Nuts, nes; Oats; Oilseeds nes; Okra; Olives; Onions, dry; Onions, shallots, green; Oranges; Oil palm fruit; Palm kernels; Oil, palm; Papayas; Peaches and nectarines; Pears; Peas, dry; Peas, green; Pepper (piper spp.); Peppermint; Persimmons; Pigeon peas; Pineapples; Pistachios; Plantains and others; Plums and sloes; Poppy seed; Potatoes; Sweet potatoes; Pulses, nes; Pumpkins, squash and gourds; Quinces; Quinoa; Rapeseed; Raspberries; Rice, paddy; Roots and tubers, nes; Rye; Safflower seed; Sesame seed; Sorghum; Soybeans; Spices, nes; Spinach; Strawberries; String beans; Sugar beet; Sugar cane; Sugar crops, nes; Sunflower seed; Tangerines, mandarins, clementines, satsumas; Taro (cocoyam); Tea; Tomatoes; Triticale; Fruit, tropical fresh nes; Tung nuts; Vanilla; Vegetables, fresh nes; Vegetables, leguminous nes; Vetches; Walnuts, with shell; Watermelons; Wheat; Yams; Yautia (cocoyam)

Crops processed

Beer of barley; Oil, coconut (copra); Cottonseed; Oil, cottonseed; Oil, groundnut; Oil, linseed; Oil, maize; Margarine, short; Molasses; Oil, olive, virgin; Palm kernels; Oil, palm kernel; Oil, palm; Oil, rapeseed; Oil, safflower; Oil, sesame; Oil, soybean; Sugar Raw Centrifugal; Oil, sunflower; Wine

Livestock Primary

Meat, ass; Beeswax; Meat, bird nes; Meat, buffalo; Milk, whole fresh buffalo; Meat, other camelids; Milk, whole fresh camel; Meat, camel; Meat, cattle; Meat, chicken;

Meat, duck; Eggs, hen, in shell; Eggs, other bird, in shell; Meat, game; Meat, goose and guinea fowl; Milk, whole fresh goat; Meat, goat; Honey, natural; Meat, horse;

Meat, nes; Milk, whole fresh cow; Meat, mule; Offals, nes; Meat, pig; Meat, rabbit; Meat, other rodents; Meat, sheep; Milk, whole fresh sheep; Snails, not sea; Meat, turkey

Livestock Processed

Cheese, buffalo milk; Ghee, of buffalo milk; Butter, cow milk; Butter and Ghee; Cheese (All Kinds); Cheese, skimmed cow milk; Cheese, whole cow milk; Cream fresh; Ghee, butteroil of cow milk; Cheese of goat milk; Lard; Milk, skimmed cow; Evaporat \& Condensed Milk; Milk, skimmed condensed; Milk, skimmed dried; Milk, skimmed evaporated; Milk, whole condensed; Milk, whole dried; Milk, whole evaporated; Cheese, sheep milk; Butter and ghee, sheep milk; Skim Milk \& Buttermilk, dry; Whey, condensed; Whey, dry; Yoghurt

Table A.3

Variables: description and sources.

\begin{tabular}{|c|c|c|}
\hline Variables & Description & Source \\
\hline $\begin{array}{l}\text { Food Supply per } \\
\text { capita per day }\end{array}$ & $\begin{array}{l}\text { Total production, plus imports, minus exports, stock variation, and the use of agricultural products for utilization } \\
\text { different from food, in calories per capita per day, in log }\end{array}$ & FAO (2019) \\
\hline Food Security Index & Composite index that measures the multidimensional concept of food security & $\begin{array}{l}\text { Caccavale and } \\
\text { Giuffrida (2020) }\end{array}$ \\
\hline Sustainability Index & $\begin{array}{l}\text { Composite indicator that aggregates } 27 \text { indicators grouped in four dimensions aiming to characterize the sustainability } \\
\text { of food systems }\end{array}$ & Béné et al. (2019b) \\
\hline Agr. TFP (ln) & Agricultural total factor productivity index (base year $2005=100$ ) in $\log$ & Fuglie (2012) \\
\hline Human capital & Index of human capital: average years of schooling and the returns to education & Feenstra et al. (2015) \\
\hline $\begin{array}{l}\text { Imports per capita } \\
\text { per day (ln) }\end{array}$ & Imports of agricultural products per capita per day in calories in log & FAO (2019) \\
\hline $\begin{array}{l}\text { Latitude in absolute } \\
\text { values }\end{array}$ & Countries latitudes in absolute values in log & BACI-CEPII (2019) \\
\hline Geographical regions & $\begin{array}{l}\text { Variable that indicates if countries belong to a geographical region: East Asia \& Pacific, Europe \& Central Asia, Latin } \\
\text { America \& Caribbean, Middle East \& North Africa, North America, South Asia, and Sub-Saharan Africa }\end{array}$ & World Bank (2019) \\
\hline
\end{tabular}


Table A.4

Summary statistics of dependent and independent variables. 1993-2013.

\begin{tabular}{|c|c|c|c|c|c|}
\hline Variable & Obs. & Mean & Std. Dev. & Min & Max \\
\hline Food Supply per capita per day & 3,549 & 2.706 & 0.474 & 1.508 & 3.828 \\
\hline Food Security Index & 3,402 & 0.614 & 0.155 & 0.203 & 0.938 \\
\hline Sustainability Index & 1,292 & 0.495 & 0.128 & 0.149 & 0.740 \\
\hline Entropy & 3,549 & 2.407 & 0.540 & 0.475 & 3.816 \\
\hline Coherence & 3,549 & 0.868 & 0.409 & 0.147 & 2.005 \\
\hline Fitness (ln) & 3,549 & -0.621 & 1.141 & -3.628 & 2.927 \\
\hline Agr. TFP (ln) & 3,252 & 4.574 & 0.154 & 3.957 & 5.188 \\
\hline Human capital & 2,814 & 2.386 & 0.691 & 1.041 & 3.726 \\
\hline Imports per capita per day (ln) & 3,549 & 0.263 & 1.049 & -3.992 & 3.135 \\
\hline Latitude in absolute values & 3,549 & 26.096 & 16.578 & 0.200 & 64.150 \\
\hline
\end{tabular}

\section{References}

Achicanoy, H., Alvarez, P., Béné, C., Prager, S., Lamotte, L., \& Bonilla Cedrez, C. (2019). Sustainable food systems global index. Harvard Dataverse. Available at: https://doi.org/10.7910/DVN/GYEG59..

Aguiar, S., Texeira, M., Garibaldi, L. A., \& Jobbágy, E. G. (2020). Global changes in crop diversity: Trade rather than production enriches supply. Global Food Security, 26 100385.

Aizen, M. A., Aguiar, S., Biesmeijer, J. C., Garibaldi, L. A., Inouye, D. W., Jung, C., Martins, D. J., Medel, R., Morales, C. L., Ngo, H., et al. (2019). Global agricultural productivity is threatened by increasing pollinator dependence without a parallel increase in crop diversification. Global Change Biology, 25(10), 3516-3527.

Arellano, M., \& Bover, O. (1995). Another look at the instrumental variable estimation of error-components models. Journal of Econometrics, 68(1), 29-51.

BACI-CEPII (2019). GeoDist database. Available at:http://www.cepii.fr/CEPII/en/ bdd_modele/presentation.asp?id=6..

Balassa, B. (1965). Trade liberalization and "revealed" comparative advantage. Manchester School, 33, 99-123.

Balland, P. A., \& Rigby, D. (2017). The geography of complex knowledge. Economic Geography, 93(1), 1-23.

Barabási, A.-L., Menichetti, G., \& Loscalzo, J. (2020). The unmapped chemical complexity of our diet. Nature Food, 1(1), 33-37.

Battisti, D. S., \& Naylor, R. L. (2009). Historical warnings of future food insecurity with unprecedented seasonal heat. Science, 323(5911), 240-244.

Béné, C., Oosterveer, P., Lamotte, L., Brouwer, I., de Haan, S., Prager, S., Talsma, E., \& Khoury, C. (2019a). When food systems meet sustainability-current narratives and implications for actions. World Development, 113, 116-130.

Béné, C., Prager, S., Achicanoy, H., Alvarez Toro, P., Lamotte, L., Bonilla Cedrez, C., \& Mapes, B. (2019b). Global map indicators of food system sustainability. Scientific Data, 6(279), 1-15.

Béné, C., Prager, S., Achicanoy, H., Alvarez Toro, P., Lamottea, L., Bonilla Cedrez, C., \& Mapes, B. (2019c). Understanding food systems drivers: A critical review of the literature. Global Food Security, 23, 149-159.

Bentham, J., Singh, G. M., Danaei, G., Green, R., Lin, J. K., Stevens, G. A., Farzadfar, F., Bennett, J. E., Di Cesare, M., Dangour, A. D., et al. (2020). Multidimensional characterization of global food supply from 1961 to 2013. Nature Food, 1(1), 70-75.

Blesh, J., Hoey, L., Jones, A. D., Friedmann, H., \& Perfecto, I. (2019). Development pathways toward "zero hunger.". World Development, 118, 1-14.

Blondel, V. D., Guillaume, J.-L., Lambiotte, R., \& Lefebvre, E. (2008). Fast unfolding of communities in large networks. Journal of Statistical Mechanics: Theory and Experiment, 2008(10), P10008.

Blundell, R., \& Bond, S. (1998). Initial conditions and moment restrictions in dynamic panel data models. Journal of Econometrics, 87(1), 115-143.

Borgatti, S. P. (2005). Centrality and network flow. Social Networks, 27(1), 55-71.

Brin, S., \& Page, L. (1988). The anatomy of a large-scale hypertextual web search engine. Computer Networks and ISDN Systems, 30, 107-117.

Bruno, M., Saracco, F., Squartini, T., \& Dueñas, M. (2018). Colombian export capabilities: Building the firms-products network. Entropy, 20(10), 785.

Caccavale, O. M., \& Giuffrida, V. (2020). The proteus composite index: Towards a better metric for global food security. World Development, 126104709.

Caldarelli, G., Cristelli, M., Gabrielli, A., Pietronero, L., Scala, A., \& Tacchella, A. (2012). A network analysis of countries' export flows: Firm grounds for the building blocks of the economy. PloS One, 7(10) e47278.

Campi, M., Dueñas, M., \& Fagiolo, G. (2020). How do countries specialize in agricultural production? A complex-network analysis of the global agricultural product space. Environmental Research Letters, 15(12) 124006.

Campi, M., \& Nuvolari, A. (2020). Intellectual property rights and agricultural development: Evidence from a worldwide index of iprs in agriculture (19612018). Journal of Development Studies. https://doi.org/10.1080/ 00220388.2020.1817395.

Cassidy, E. S., West, P. C., Gerber, J. S., \& Foley, J. A. (2013). Redefining agricultural yields: From tonnes to people nourished per hectare. Environmental Research Letters, 8(3) 034015.

Chaudhary, A., Gustafson, D., \& Mathys, A. (2018). Multi-indicator sustainability assessment of global food systems. Nature Communications, 9(1), 848.
Choudhury, S., \& Headey, D. (2017). What drives diversification of national food supplies? a cross-country analysis. Global Food Security, 15, 85-93.

Cristelli, M., Gabrielli, A., Tacchella, A., Caldarelli, G., \& Pietronero, L. (2013). Measuring the intangibles: A metrics for the economic complexity of countries and products. PloS One, 8(8) e70726.

Donaldson, D. (2019). Comparative advantage and agricultural trade. Agricultural Economics, 50, 29-40.

Ericksen, P. J. (2008). Conceptualizing food systems for global environmental change research. Global Environmental Change, 18(1), 234-245.

Evans, L. (1998). Feeding the ten billion: Plants and population growth. Cambridge: Cambridge University Press.

FAO (2001). Food balance sheets: A handbook. Rome: Food and Agriculture Organization of the United Nations.

FAO (2019). Faostat online database ( http://faostat.fao.org/). Accessed on April 2019.

Feenstra, R. C., Inklaar, R., \& Timmer, M. P. (2015). The Next Generation of the Penn World Table. American Economic Review, 105(10), 3150-3182.

Ferrarini, B., \& Scaramozzino, P. (2016). Production complexity, adaptability and economic growth. Structural Change and Economic Dynamics, 37, 52-61.

Finaret, A. B., \& Masters, W. A. (2019). Beyond calories: The new economics of nutrition. Annual Review of Resource Economics, 11, 237-259.

Fuglie, K. O. (2012). Productivity growth and technology capital in the global agricultural economy. In K. Fuglie, S. Wang, \& V. Ball (Eds.), Productivity Growth in Agriculture: An International Perspective (pp. 335-368). Wallingford: CAB International.

Godfray, H. C. J., Beddington, J. R., Crute, I. R., Haddad, L., Lawrence, D., Muir, J. F. Pretty, J., Robinson, S., Thomas, S. M., \& Toulmin, C. (2010). Food security: The challenge of feeding 9 billion people. Science, 327(5967), 812-818.

Gornall, J., Betts, R., Burke, E., Clark, R., Camp, J., Willett, K., \& Wiltshire, A. (2010). Implications of climate change for agricultural productivity in the early twentyfirst century. Philosophical Transactions of the Royal Society B: Biological Sciences, 365(1554), 2973-2989.

Hausmann, R., Hidalgo, C. A., Bustos, S., Coscia, M., Simoes, A., \& Yildirim, M. A. (2014). The atlas of economic complexity: Mapping paths to prosperity. Cambridge, Massachusetts: MIT Press.

Hausmann, R., Hwang, J., \& Rodrik, D. (2007). What you export matters. Journal of Economic Growth, 12(1), 1-25.

Hazell, P., \& Wood, S. (2007). Drivers of change in global agriculture. Philosophical Transactions of the Royal Society B: Biological Sciences, 363(1491), 495-515.

Heckscher, E. F., \& Ohlin, B. G. (1991). Heckscher-Ohlin trade theory. The MIT Press.

Hidalgo, C. A., \& Hausmann, R. (2009). The building blocks of economic complexity. Proceedings of the National Academy of Sciences, 106(26), 10570-10575.

Hidalgo, C. A., Klinger, B., Barabási, A.-L., \& Hausmann, R. (2007). The product space conditions the development of nations. Science, 317(5837), 482-487.

Johnston, J. L., Fanzo, J. C., \& Cogill, B. (2014). Understanding sustainable diets: A descriptive analysis of the determinants and processes that influence diets and their impact on health, food security, and environmental sustainability. Advances in Nutrition, 5(4), 418-429.

Khoury, C. K., Achicanoy, H. A., Bjorkman, A. D., Navarro-Racines, C., Guarino, L., Flores-Palacios, X., Engels, J. M., Wiersema, J. H., Dempewolf, H., Sotelo, S., et al. (2016). Origins of food crops connect countries worldwide. Proceedings of the Royal Society B: Biological Sciences, 283(1832), 20160792.

Khoury, C. K., Bjorkman, A. D., Dempewolf, H., Ramirez-Villegas, J., Guarino, L., Jarvis, A., Rieseberg, L. H., \& Struik, P. C. (2014). Increasing homogeneity in global food supplies and the implications for food security. Proceedings of the National Academy of Sciences, 111(11), 4001-4006.

Kinnunen, P., Guillaume, J. H., Taka, M., D’Odorico, P., Siebert, S., Puma, M. J., Jalava, M., \& Kummu, M. (2020). Local food crop production can fulfil demand for less than one-third of the population. Nature Food, 1(4), 229-237.

Lall, S. (2000). The technological structure and performance of developing country manufactured exports, 1985-98. Oxford Development Studies, 28(3), 337-369.

Liu, J., Mooney, H., Hull, V., Davis, S. J., Gaskell, J., Hertel, T., Lubchenco, J., Seto, K. C. Gleick, P., Kremen, C., et al. (2015). Systems integration for global sustainability. Science, 347(6225).

Lowder, S. K., Skoet, J., \& Raney, T. (2016). The number, size, and distribution of farms, smallholder farms, and family farms worldwide. World Development, 87, $16-29$. 
Marlow, H. J., Hayes, W. K., Soret, S., Carter, R. L., Schwab, E. R., \& Sabate, J. (2009). Diet and the environment: Does what you eat matter? The American Journal of Clinical Nutrition, 89(5), 1699S-1703S.

Martin, A. R., Cadotte, M. W., Isaac, M. E., Milla, R., Vile, D., \& Violle, C. (2019). Regional and global shifts in crop diversity through the Anthropocene. PloS One, 14(2) e0209788.

Morrison, G., Buldyrev, S. V., Imbruno, M., Arrieta, O., Rungi, A., Riccaboni, M., \& Pammolli, F. (2017). On economic complexity and the fitness of nations. Scientific Reports, 7(1), 15332.

Muhammad, A., Seale, J.L., Meade, B., \& Regmi, A. (2011). International evidence on food consumption patterns: an update using 2005 international comparison program data. USDA-ERS technical bulletin, (1929)..

Muller, A., Schader, C., Scialabba, N. E.-H., Brüggemann, J., Isensee, A., Erb, K.-H., Smith, P., Klocke, P., Leiber, F., Stolze, M., et al. (2017). Strategies for feeding the world more sustainably with organic agriculture. Nature Communications, 8(1), $1-13$.

Nelson, E. J., Helmus, M. R., Cavender-Bares, J., Polasky, S., Lasky, J. R., Zanne, A. E., Pearse, W. D., Kraft, N. J., Miteva, D. A., \& Fagan, W. F. (2016). Commercial plant production and consumption still follow the latitudinal gradient in species diversity despite economic globalization. PloS One, 11(10) e0163002.

Nonhebel, S., \& Kastner, T. (2011). Changing demand for food, livestock feed and biofuels in the past and in the near future. Livestock Science, 139(1-2), 3-10.

Oosterveer, P. (2007). Global governance of food production and consumption: issues and challenges. Edward Elgar Publishing.

Pardey, P. G., Chan-Kang, C., Dehmer, S. P., \& Beddow, J. M. (2016). Agricultural r\&d is on the move. Nature News, 537(7620), 301.

Petralia, S., Balland, P. A., \& Morrison, A. (2017). Climbing the ladder of technological development. Research Policy, 46(5), 956-969.

Pugliese, E., Zaccaria, A., \& Pietronero, L. (2016). On the convergence of the fitnesscomplexity algorithm. The European Physical Journal Special Topics, 225(10), 1893-1911.

Puma, M. J. (2019). Resilience of the global food system. Nature Sustainability, 2(4), 260.

Remans, R., Wood, S. A., Saha, N., Anderman, T. L., \& DeFries, R. S. (2014). Measuring nutritional diversity of national food supplies. Global Food Security, 3(3-4), $174-182$.
Ricardo, D. (1817). On the principles of political economy and taxation. London: John Murray.

Springmann, M., Clark, M., Mason-D’Croz, D., Wiebe, K., Bodirsky, B. L., Lassaletta, L., De Vries, W., Vermeulen, S. J., Herrero, M., Carlson, K. M., et al. (2018). Options for keeping the food system within environmental limits. Nature, 562(7728), 519-525.

Steinfeld, H., Gerber, P., Wassenaar, T., Castel, V., Rosales, M., Rosales, M., \& de Haan, C. (2006). Livestock's long shadow: Environmental issues and options. Food and Agriculture Organization.

Tacchella, A., Cristelli, M., Caldarelli, G., Gabrielli, A., \& Pietronero, L. (2012). A new metrics for countries' fitness and products' complexity. Scientific Reports, 2, 723.

Teece, D. J., Rumelt, R., Dosi, G., \& Winter, S. (1994). Understanding corporate coherence: Theory and evidence. Journal of Economic Behavior \& Organization, 23 (1), 1-30.

Tilman, D., \& Clark, M. (2014). Global diets link environmental sustainability and human health. Nature, 515(7528), 518-522.

Torreggiani, S., Mangioni, G., Puma, M. J., \& Fagiolo, G. (2018). Identifying the community structure of the food-trade international multi-network. Environmental Research Letters, 13(5) 054026.

United Nations (2015). Resolution adopted by the General Assembly on 25 September 2015. UN General Assembly. Available at: https://www.un.org/en/ development/desa/population/ migration/generalassembly/docs/globalcompact/A_RES_70_1_E.pdf.

Vermeulen, S., Park, T., Khoury, C., \& Béné, C. (2020). Changing diets and the transformation of the global food system. Annals of the New York Academy of Sciences., Special Issue: Annals Reports:1-15..

Woods, J., Williams, A., Hughes, J. K., Black, M., \& Murphy, R. (2010). Energy and the food system. Philosophical Transactions of the Royal Society B: Biological Sciences, 365(1554), 2991-3006.

World Bank (2019). World Development Indicators. The World Bank Group. Available at: data.worldbank.org..

Zaccaria, A., Cristelli, M., Tacchella, A., \& Pietronero, L. (2014). How the taxonomy of products drives the economic development of countries. PloS One, 9(12) e113770. 